\title{
Guide to the fresh water fishes in Tubod River, Lake Danao and Inawasan River in Leyte, Philippines.
}

\author{
Wasantha S. Weliange', Jimmy Pogosa², Chandima Lankaadikara', Maria \\ Leichtfried $^{3}$, and Friedhelm Göltenboth ${ }^{4}$ \\ 'Department of Zoology, University of Kelaniya, 11600, Sri Lanka; \\ ${ }^{2}$ Institute of Tropical Ecology, Visayas State University (formerly Leyte State \\ University), Baybay City, Leyte, Philippines; \\ ${ }^{3}$ Institute for Limnology of the Austrian Academy of Sciences, Mondseestr. 9, A-5310 \\ Mondsee, Austria; \\ "University of Hohenheim. Institute for Plant Production and Agroecology in the \\ Tropics and Subtropics, Garbenstr. 13, D-70593 Stuttgart. Germany
}

\begin{abstract}
Very little research has yet been done on fresh water fishes in the Philippines. The paper presents the description and key for the identification of 21 fresh water fish species occurring in Tubod River (18 species), Lake Danao (4 species) and its outlet Inawasan River (1species) in Leyte, Philippines. It also provides some notes on the ecology of the fish species.
\end{abstract}

Keywords: fresh water fishes, Tubod River, Lake Danao, Inawasan River

\section{INTRODUCTION}

A guide for the identification of fish species in Tubod River, Lake Danao and Inawasan River was prepared during the International Tropical Ecology Workshops carried out from 2001 - 2003. Preliminary investigations in these 
lotic and lentic habitats were pioneered by Leichtfried et al. (2002), Göltenboth et al. (2005), Weliange \& Pogosa (2005), and Weliange (2002). Riparian villages are familiar with the fish species occurring in these habitats and use local names for identifying most of them. Local names are available in two forms; fish species with prominent and outstanding features have unique names and the fish species with similar body shapes and sizes are given names to represent a fish guild. The use of local names to define a group of fish species with similar body shapes, sizes and behaviors is a common practice in many other tropical countries such as Sri Lanka, where surface feeders, water column feeders, benthic ambush predators and benthic bottom feeders are considered as ecological units and given group names, and larger carnivores are given unique local names. Behavior patterns of fishes, preferred habitats, migration patterns and breading seasons are known to the villagers in the Tubod River and Lake Danao, who associate these freshwater habitats for various day to day activities and harvesting of fishes and other animals for food. Pollution from agriculture, human waste, fishing for aquarium trade and waste dumping are not yet threatening these habitats due to the fact that they are situated above the villages. Development projects that would change the catchments properties such as introduction of new fish species for cage and pond culture or over fishing can have impacts on the habitats of the fish species and to peril the populations of freshwater fishes in these habitats. According to the elderly villagers, fish populations have declined during the past few years.

\section{Notes on contents and format of the guide}

The description and keys assume a basic knowledge of fish form and families, and concentrate on the separation of genera and species. Essentially prepared for the identification of adults, the keys should also enable the identification of juveniles of medium to large-sized species. Families are arranged in a phylogenetic order and nomenclature follows the Kottelat et al. (1993), which is a checklist of freshwater fishes in Indo-Malaysian region. Local names for the fish species and the meanings were obtained from the villagers around the habitat and provided with the local names. Food habits and preferred habitat of occurrence also were investigated (Weliange and Pogosa, 2005). 


\section{Area of sampling and sampling methods}

Tubod River is a second order stream that flows from Mount Pangasugan to the sea on the west side of Leyte island. More detailed description about the Tubod River is given in Leichtfried et al. (2002). Tubod River was sampled for fishes from bunk house $\left(10^{\circ} 44^{\prime} 18^{\prime \prime}\right.$ North $-124^{\circ} 49^{\prime} 79^{\prime \prime}$ East $)$ at the most upstream to the Cienda Barangay (village) at the down stream $\left(10^{\circ}\right.$ $43^{\prime} 34^{\prime \prime}$ North $-24^{\circ} 47^{\prime} 87^{\prime \prime}$ East). Major sampling sites were the bunk house, recreation area, eel pond and Cienda Barangay (Figure 1). Lake Danao is a natural caldron shape, deep lake (Göltenboth et al., 2005) and its out let river; Inawasan is originating from the overflow of the lake Danao $\left(1^{\circ} 03^{\prime}\right.$ $94^{\prime \prime}$ North - $124^{\circ} 47^{\prime} 87^{\prime \prime}$ East). In Inawasan stream, about a $50 \mathrm{~m}$ stretch was sampled and only inshore areas of Lake Danao were sampled for fishes. Tubod River and Inawasan River were sampled with locally made harpoons, trapping with nets of $5 \mathrm{~mm}$ mesh size, and driving fishes by river bed alterations to make channels towards traps and trap nets. Wading depth of Lake Danao was sampled with harpooning and the inshore area with submerged vegetation was sampled with a gill net ranging from $8,12,16,20,24,33,60,76$ and 90 $\mathrm{mm}$ stretch mesh size. Beach seining with $1 \mathrm{~mm}$ mesh size net was done in few shallow areas. Angling was performed at night with different hook sizes in order to catch carnivorous fishes.

\section{Body measurements}

Total length (TL) of fish species was given after the Fishbase (Froese and Pauly, 2000) and the local names obtained by the villagers. Fourteen other morphological variables ( 5 coded and 9 mensural variables) were also measured, which would be given in else where.

\section{Scale counts}

Three scale counts were done according to the following definitions:

- Lateral line series; a count from the first pore-bearing scale posterior to the upper edge of the gill cover to the pore-bearing scale at, or on the line of flexure between, the caudle peduncle and caudle fin.

- Pre-dorsal scales; a count of scales from the lateral line to the origin of the dorsal fin. 
- Pre-opercle scales; a count of scales from the anterior edge of the orbit to the tip of the snout.

Key for the identification of the freshwater fish species in Tubod River, Lake Danao and Inawasan River

1a Body elongated and bearing a single dorsal fin

Ib Body not elongated or when elongated bearing

two dorsal fins

2a Dorsal, caudal and anal fins united / continuous,

body mottled; maxillary and mandibulary teeth

bands with a longitudinal groove without teeth (Figure 2);

distance between imaginary verticals through

dorsal origin and anus 14-19\% TL

- Anguilla marmorata (Figure 12).

2b Dorsal, caudal and anal fins separated/not united

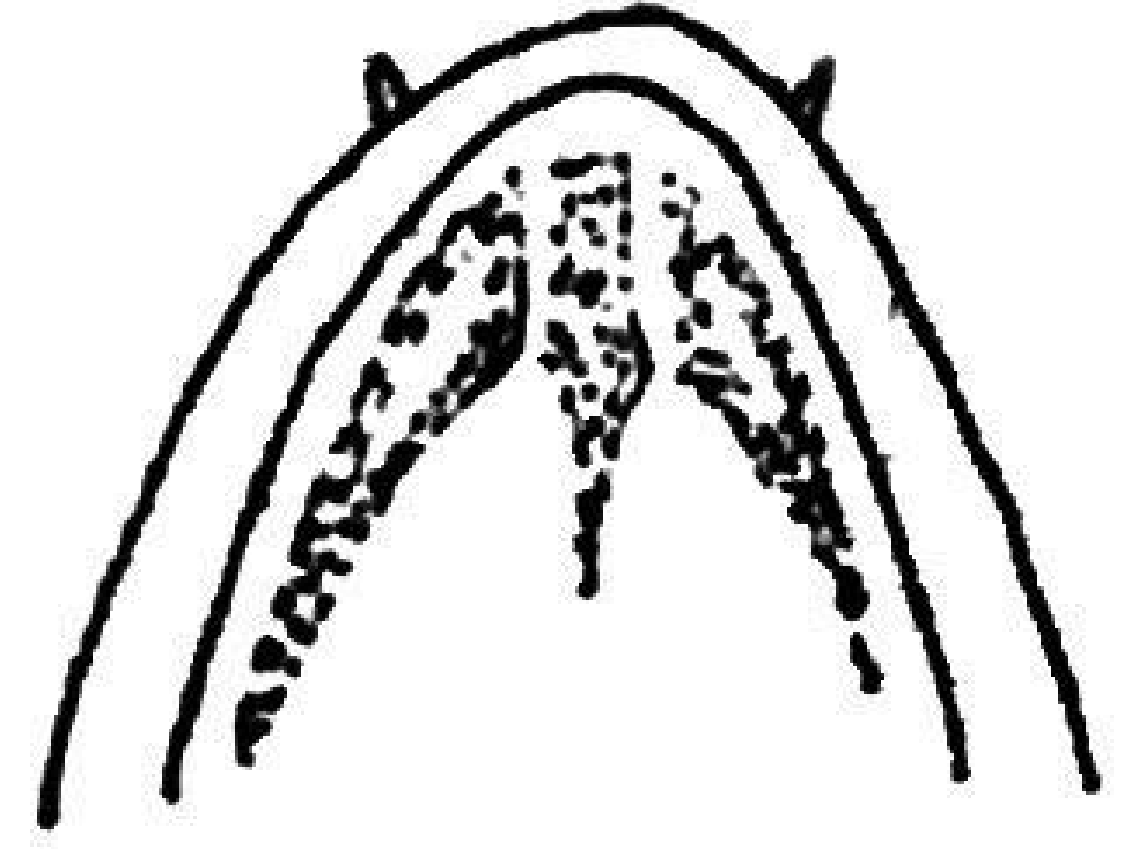

(a)

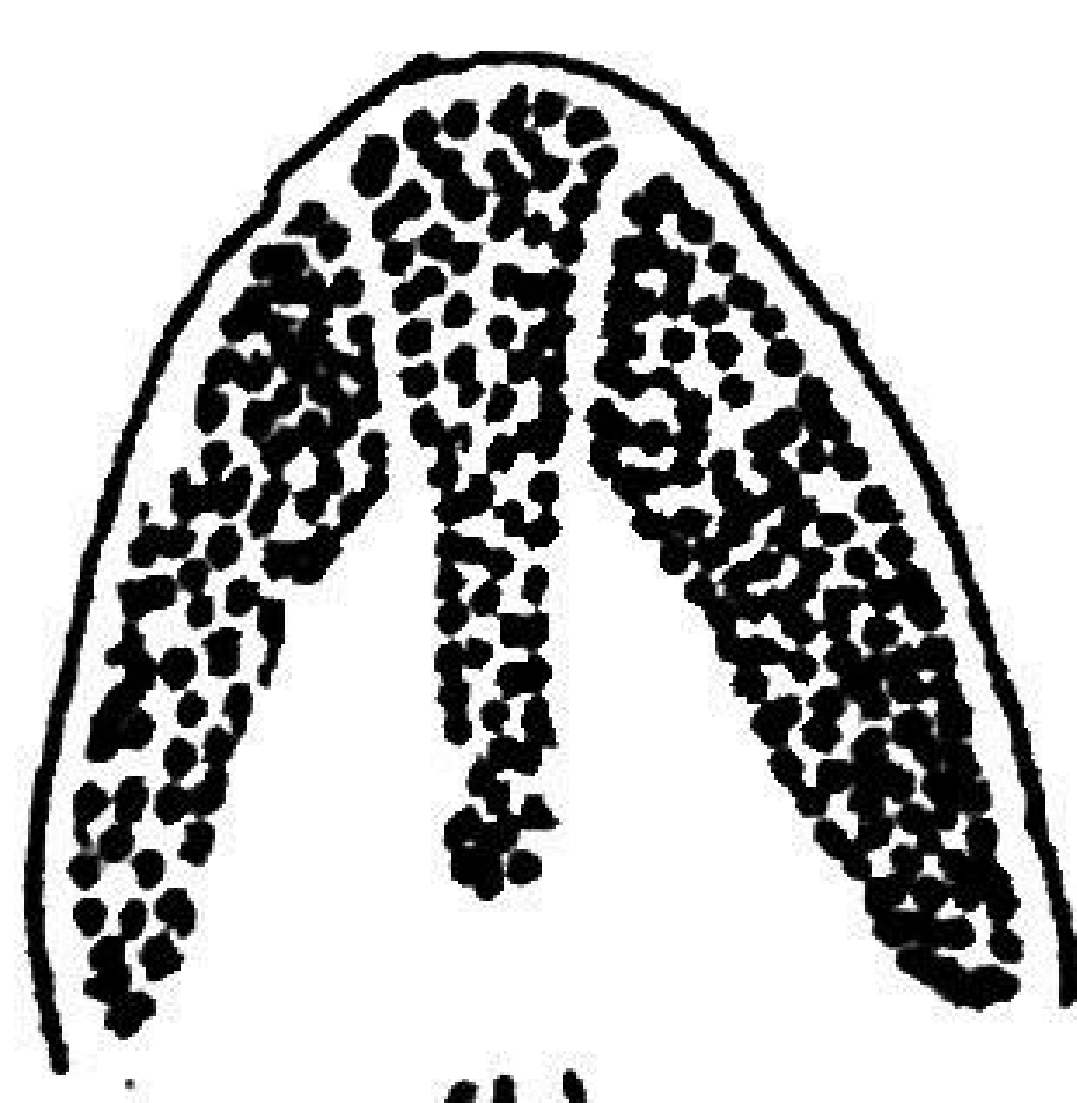

(b)

Figure 2. Arrangement of teeth in lower jaw (a) and upper jaw (b) in Anguilla marmorata
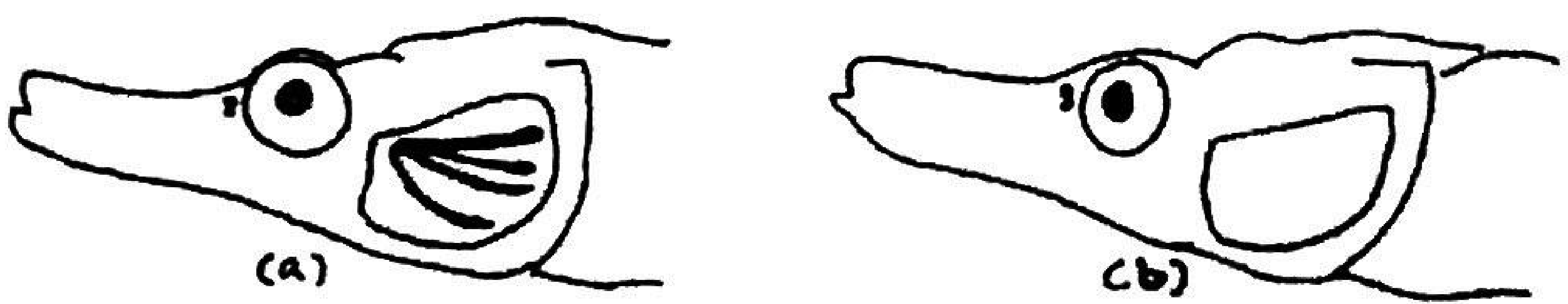

Figure 3. Operculum with complete (a) and vestigial or absent (b) longitudinal ridges in pipefish 


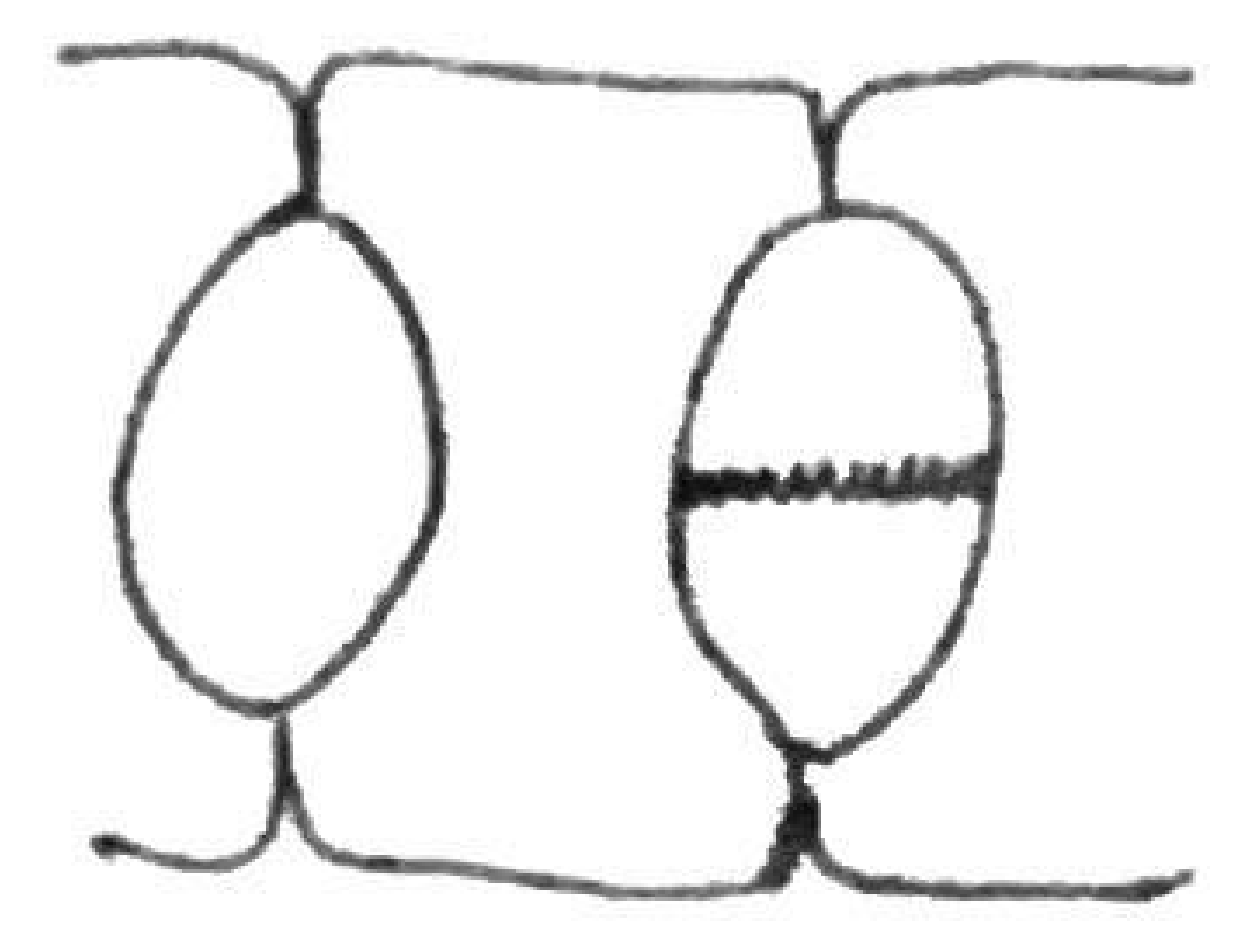

(a) (b)

Figure 4. Unkeeled (a) and keeled (b) scutella in pipefish

3a Operculum with a longitudinal ridge (Figure 3a). Snout depth 3.64.8 times in its TL. Scutella without keel (Figure 4a) sometimes keeled on dorsal side 1 st and 2 nd trunk ridges (Figure 4b). Ocelli on lateral trunk ridge - Microphis ocellatus (Figure 38).

$3 \mathrm{~b} \quad$ Operculum without ridges (Figure $3 \mathrm{~b}$ ). Lateral and inferior trunk ridges distinct. Large specimens with dark spots on pectoral base and ocellate spots on side of trunk - Microphis argulus (Figure 39).

4a Pelvic fins united to form a sucking disc (Figure 5) 5

$4 \mathrm{~b} \quad$ Pelvic fins not united

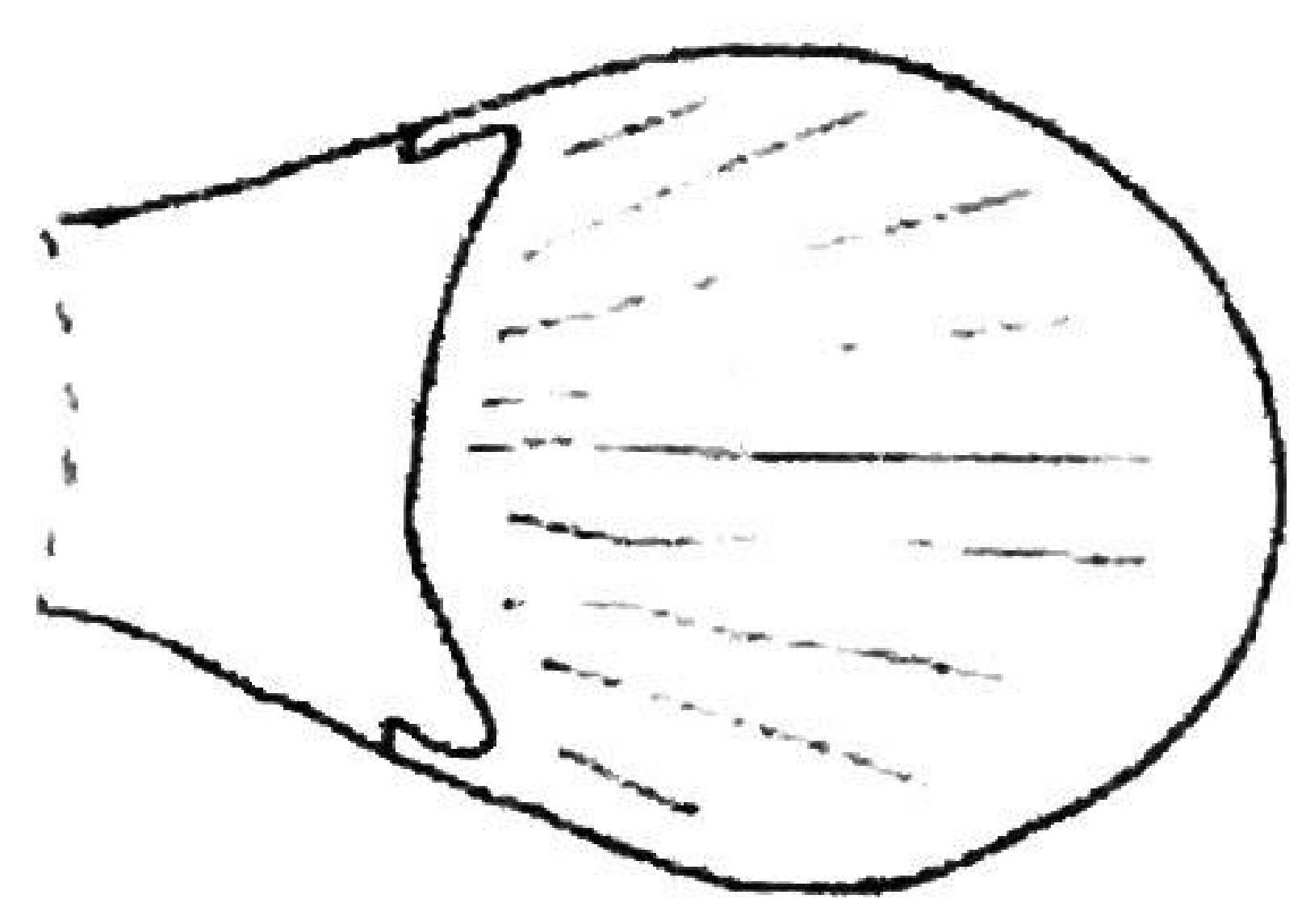

Figure 5. United pelvic fins in a form of a sucking disk in Gobiidae

5a Body scaled

5a Body naked; body depth 4.0-5.0 in SL.

- Schismatogobius marmoratus (Figure 29)

6a Teeth on lower jaw in a single row 7

$6 \mathrm{~b}$ Teeth on lower jaw in two or more rows

7a Pelvic disc adherent to the body (Figure 6a). 
Upper lip with one median and two lateral clefts (Figure 7).

Lateral scales 50-60, pre-dorsal scales 64; light brown with about 8 bars across back; caudal orange with an upper and lower submarginal stripes, most conspicuous in female

- Sicypterus micrurus (Figure 22)

$7 \mathrm{~b}$

Pelvic disc not adherent to the body (Figure 6b)
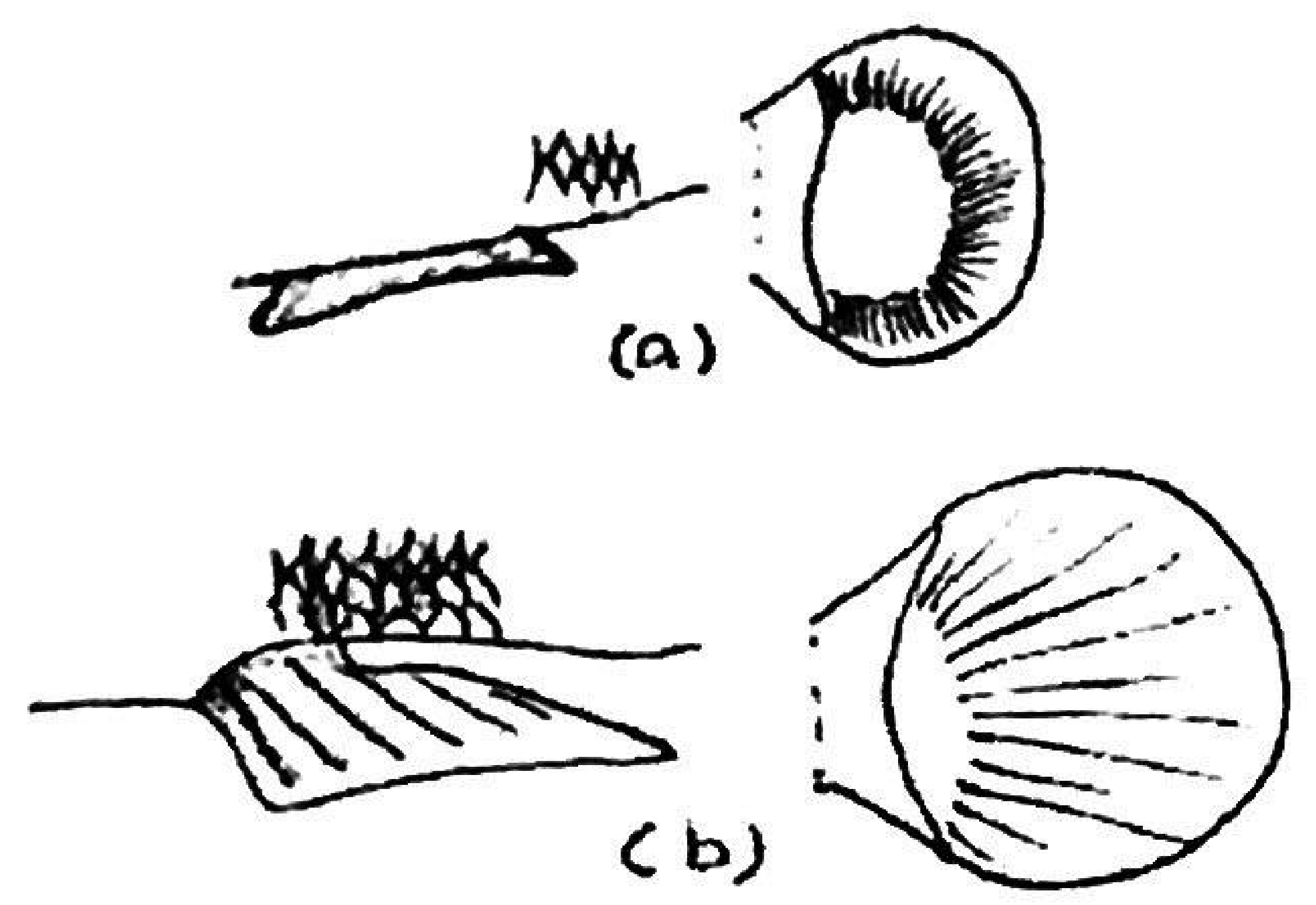

Figure 6. United pelvic fin adherent to body (a), separate from the body (b)

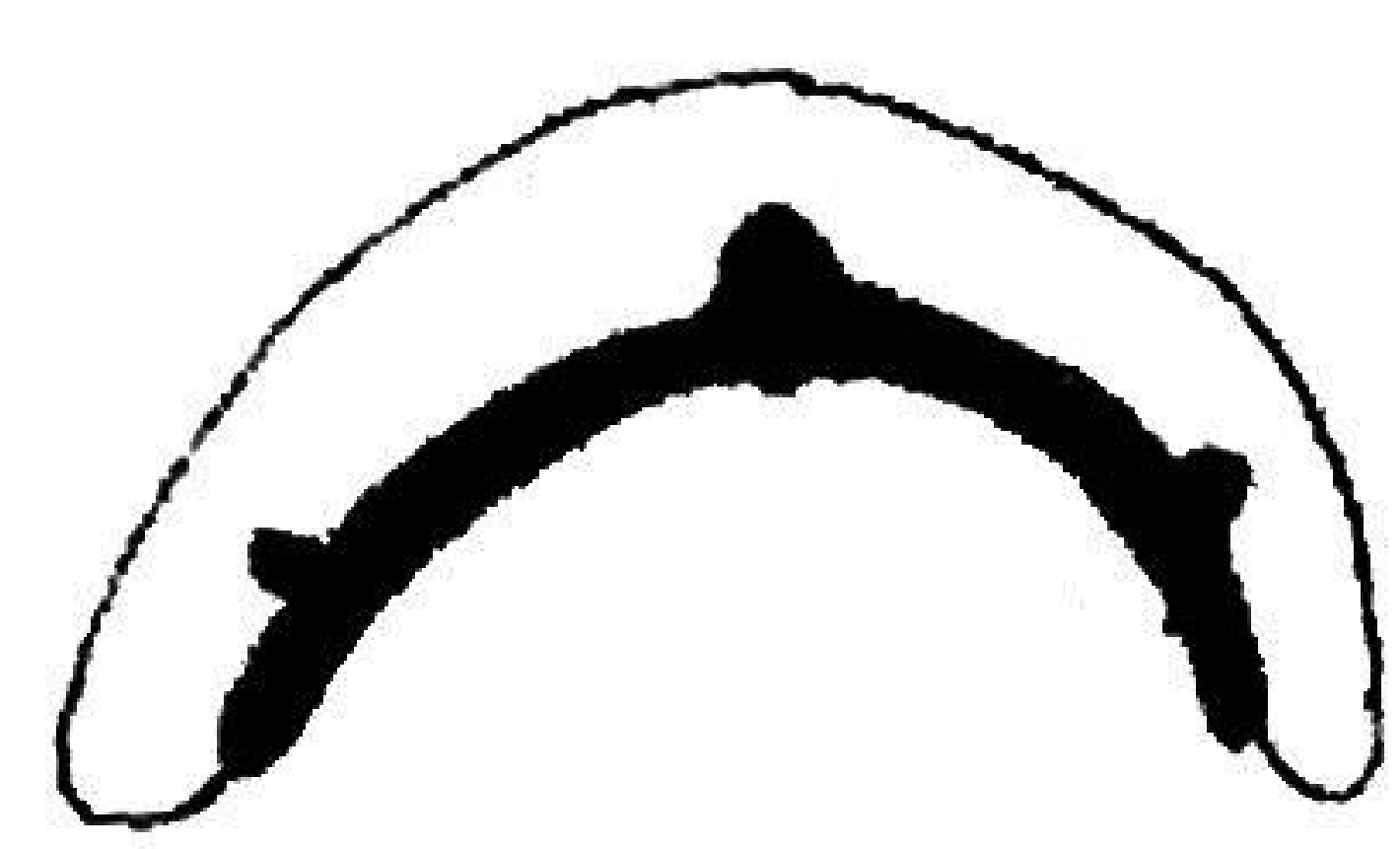

Figure 7. Three clefts in the upper lip are shown between upper lip and mouth gape (black)

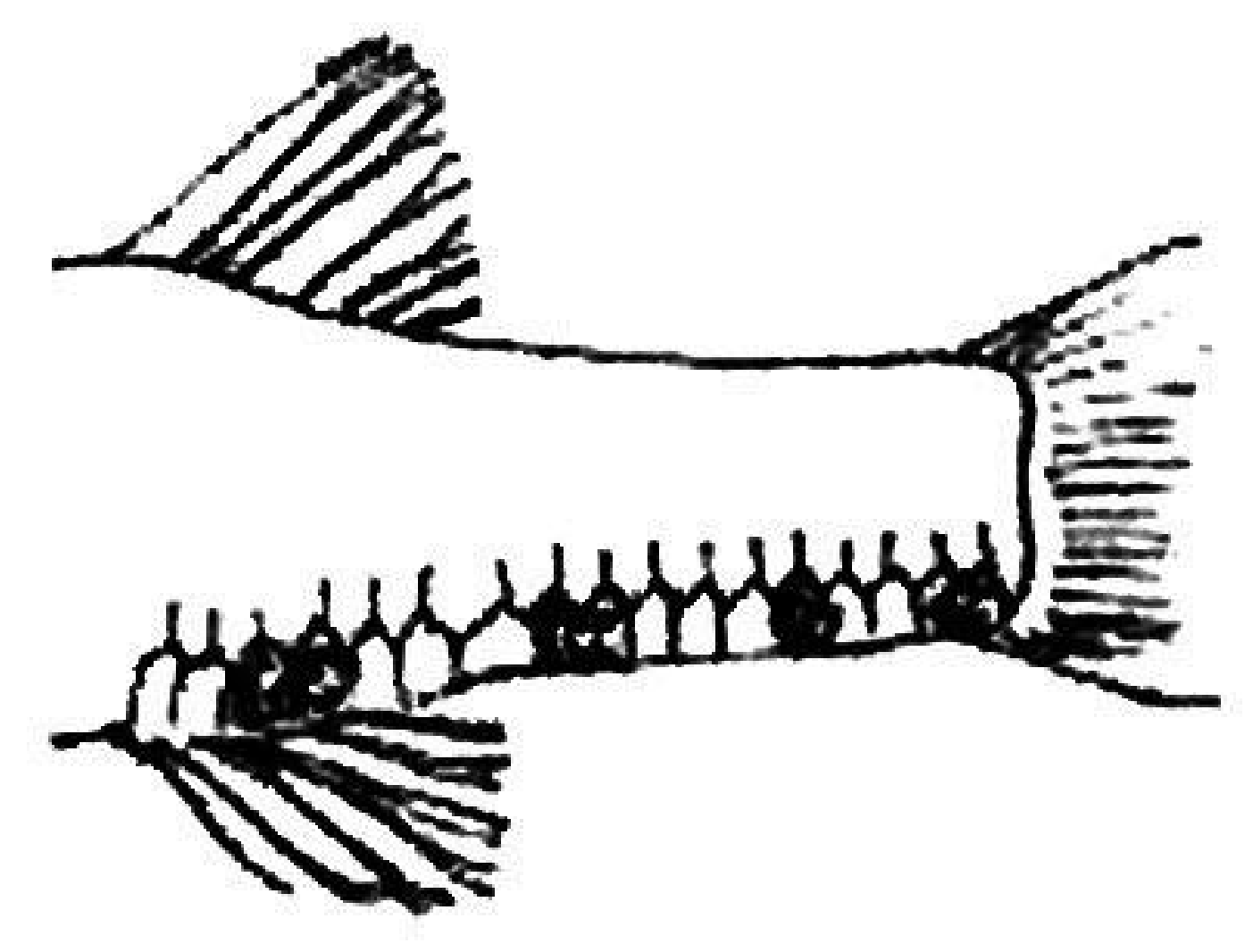

Figure 8. Black spots along lower margin of caudal peduncle 


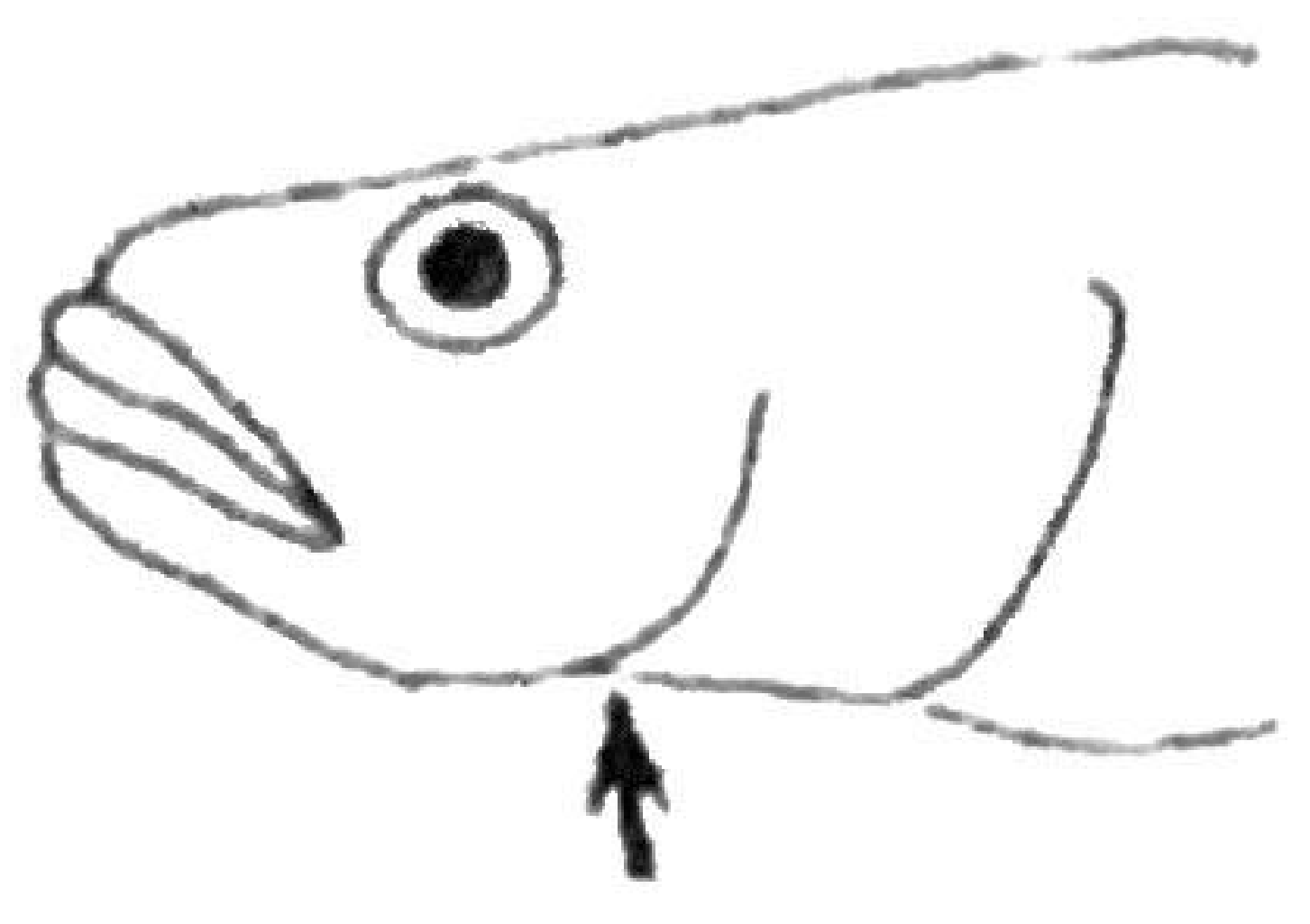

Figure 9. Anterior extent of gill opening of Glossogobius sp.

8a Teeth in upper jaw closely set more or less tricuspid. Females and juveniles yellowish brown with two black stripes; in male this pattern is obscured; 33-35 lateral row scales; 12-14 pre-dorsal scales - Stiphodon elegans (Figure 23)

8b Teeth on upper jaw tricuspid. Lateral row scales 32-33; head dark; male body orange red with a broad dark bar below first dorsal; two narrow dark bars below second dorsal and one bar on caudal peduncle. Female plane brown Sicyophus zosterophorum (Figure 21).

9a Head pores present (some times pre-opercular pores only)

9b Head pores absent; body fully scaled, with three black spots along lower margin of caudal peduncle (Figure 8) - Pandaka pygmaea (Figure 30).

10a Gill opening extending only to level of lower most pectoral ray or slightly below

- Favonigobius reichei (Figure 27).

$10 \mathrm{~b}$ Gill opening extending to below rear margin of pre-opercle or further forward (Figure 8)

- Glossogobius giuris (Figure 31).

11a Bearing four pairs of barbles around mouth; relatively large head (4.0-5.0 in SL); relatively few dorsal and anal rays; anterior boarder of frontal reaches a line through the middle of the eye or further forward - Clarias batrachus (Figure 13). 
$11 \mathrm{~b}$ Do not bear four pairs of barbles around the mouth

12a Bear two dorsal fins 13

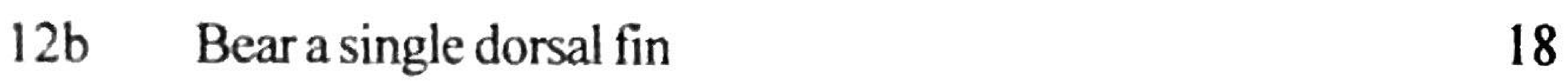

13a Caudal fin forked, lateral row scales 40-45;

maxillary not reaching to below middle of the eye;

snout shorter that eye; length of base of soft anal larger than that of soft dorsal, 16-19 gill rakers on lower part of gill arch Kuhlia marginata (Figure 33).

13b Caudal fin not forked

14a Pelvics close together, body compressed round or only slightly depressed

14b Pelvics widely separated, body depressed, flat

- Rhyacichthys aspro (Figure 32)

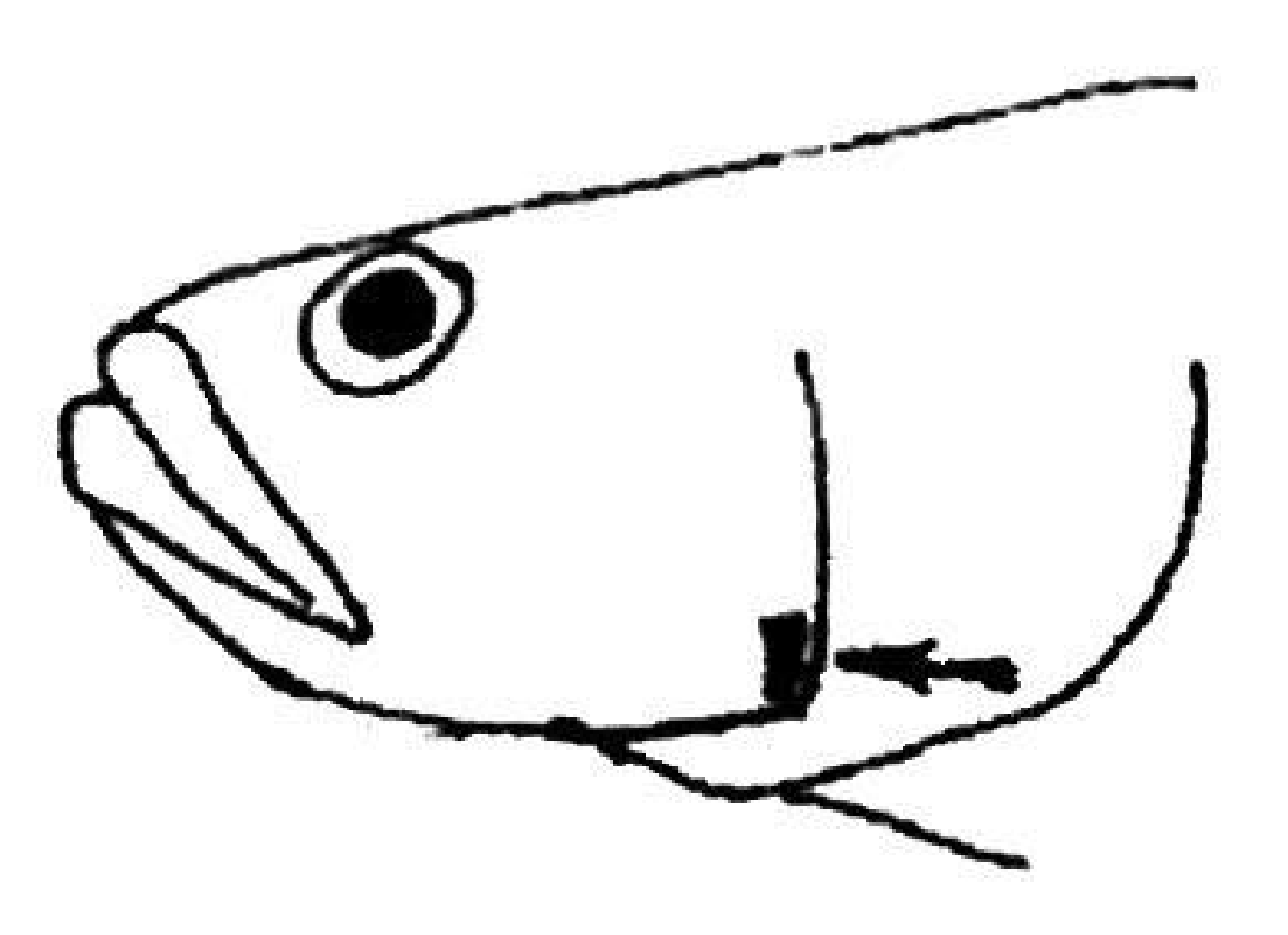

Figure 10. Pre-opercle of Eleotoris sp. showing downward curved skin. Curved skin spine is shown in an arrow

15a Angle of pre-opercle with a downward curved strong spine (Figure 10), lateral row scales 46-58; usually 18-19 pectoral rays; 12-13 gill rackers on first gill arch; two longitudinal rows of papillae on opercle met posteriorly - Eleotris melanosoma (Figure 16).

15b Angle of pectoral do not possess a downward curved spine

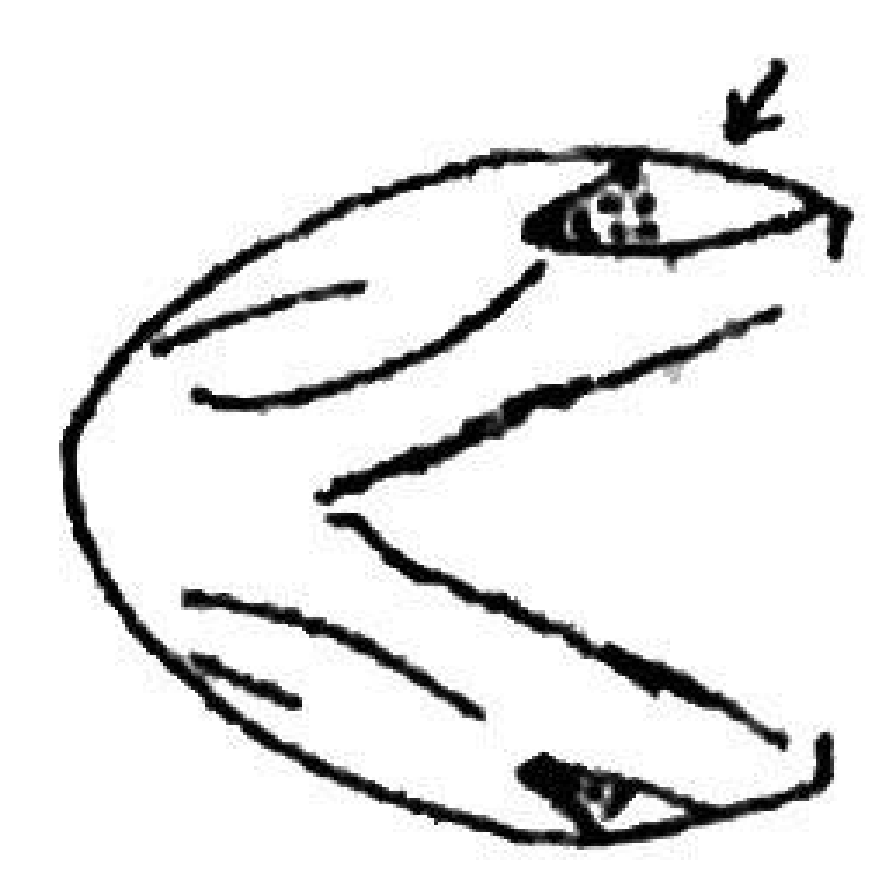

Figure 11. First branchiostegal ending anteriorly in a spine (dotted) 
16a First branchiostegal ending anteriorly in a spine (Figure 11), head naked, lateral row scales 70; first or first and second brancheostegal end anteriorly in a spine - Belobranchus belobranchus (Figure 18).

16b Branchiostegals not ending in spines 17

17a Lateral row scales 30; pre-opercle scales 13-18; maxillary extends to below anterior part of eye - Ophieleotris aporos (Figure 19).

17b Lateral row scales 60-70; each scale with a dark spot, often forming longitudinal stripes on body - Bunaka gyrinoides (Figure 20).

18a Lateral line in two sections, the anterior curved, parallel to dorsal profile, posterior one straight along the posterior part of the body; Mostly black. several bars on body (indistinctive when adult); narrow vertical stripes on caudal; mouth points upwards; throat, pectoral, pelvics, caudal and dorsal tips red when breeding - Oreochromis niloticus (Figure 15).

$18 \mathrm{~b} \quad$ Lateral line continuous

19a Fins bear spines

19b Fins do not bear spines - Poecilia reticulate (Figure 35).

20a Short first spine and a long filamentous second spine in pelvic fin, body scaled, bluish or greenish with irregular oblique dark bars and a black blotch in middle of flank and one at caudal base - Trichogaster trichopterus (Figure 34).

20b No long filamentous spines in pelvic, anterior dorsal spines not separated from rest of the fin. Body naked - Tetraroge niger (Figure 40).

Order - Anguilliformes (Family - Anguillidae)

Anguillidae are long snake like fishes, body with small scales, pectoral fin absent, dorsal, caudal and anal fins are well developed and attached, origin of the dorsal fin is far behind gill penning. 


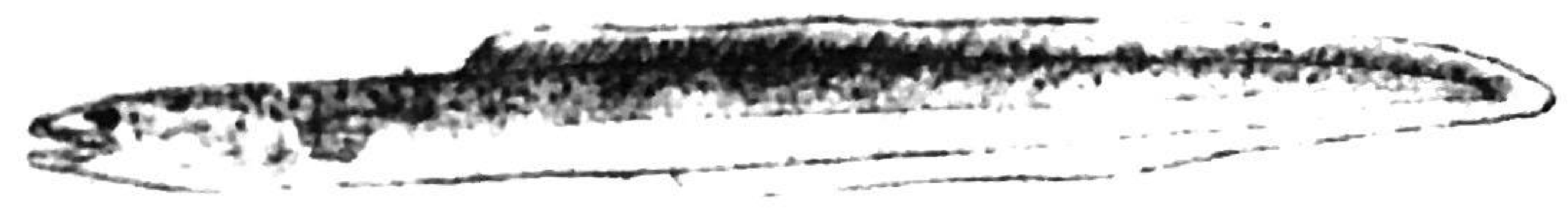

Figure 12. Anguilla marmorata (Quoy \& Gaimard, 1824)

Fishbase - Giant mottled eel, local - Kesile (long fish). TL $=900 \mathrm{~mm}$. Locality; Tubod River and Lake Danao. Camivorous. Body mottled; maxillary and mandibulary teeth bands with a longitudinal groove without teeth (Figure 1); distance between imaginary verticals through dorsal origin and anus 14$19 \% \mathrm{TL}$.

\section{Order - Siluriformes (Family - Claridae)}

1 Dorsal (if present) spineless

2 Dorsal very long, with at least 24 rays;

4 pair of barbles Claridae

Claridae are somewhat eel like with a cylindrical body with a flattened bony head, a broad transverse mouth with four pair of long barbles around it, and (usually) a single dorsal fin, which is long but lack a spine. They have an accessory air-breathing organ allowing them to survive in oxygen poor water or even out of water.

Key to genera

No adipose fin

Clarias

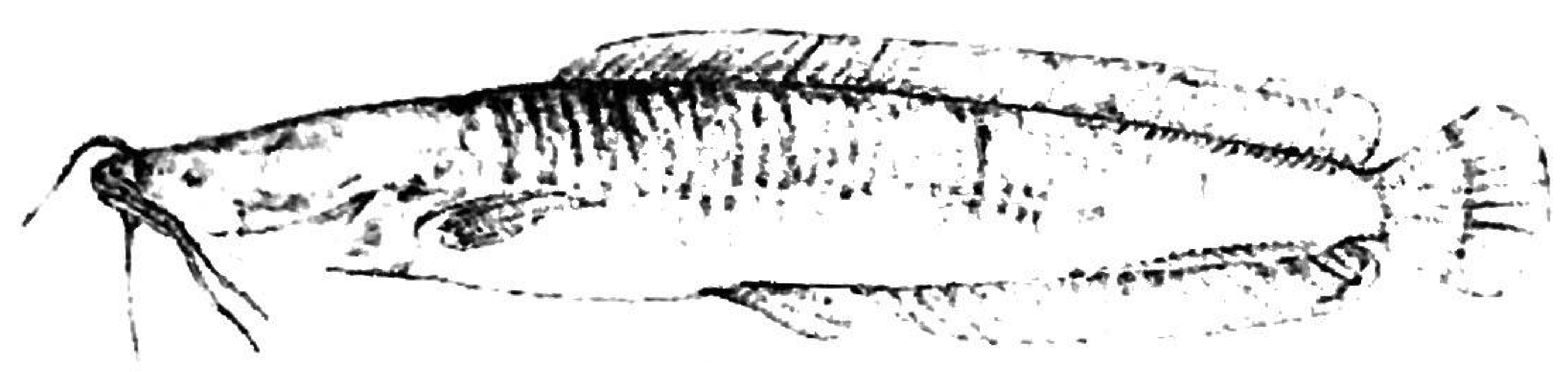

Figure 13. Clarias batrachus (Linnaeus, 1758)

Fishbase - Walking catfish, local - Imelda fish and Lele (Tubod River). $\mathrm{TL}=143 \mathrm{~mm}$. Locality; Tubod River. Introduced. Anal, caudal and dorsal 
fins not united; relatively large head (4.5-5.0 in SL); relatively few dorsal and anal rays; anterior border of frontal fontanel reaches a line through the middle of the eye or further forward; distance between dorsal and occipital process 4.5-5.5 times in distance from snout to occipital process (Figure 13).

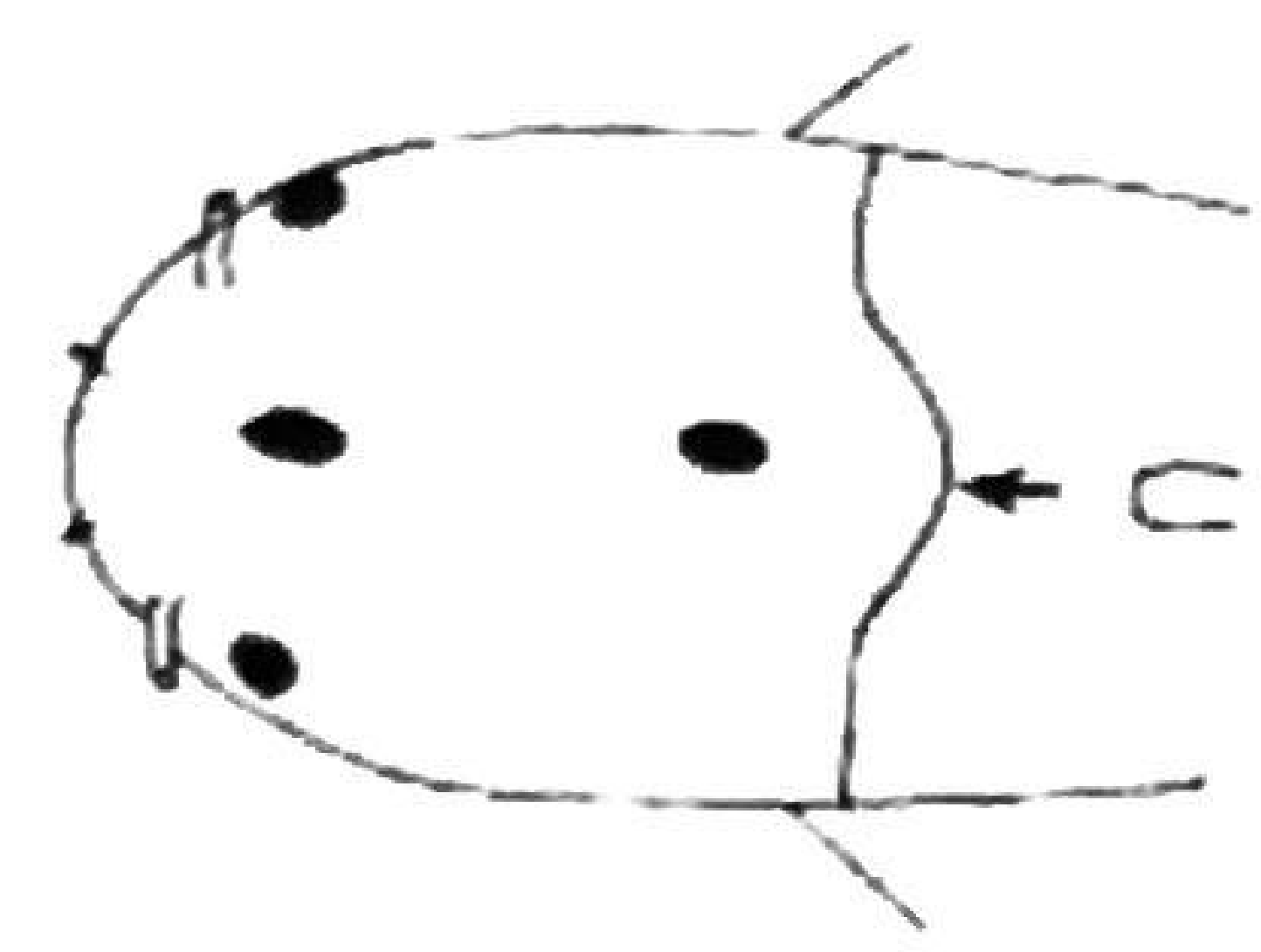

Figure 14. Frontalis (black dots) and extent of occipital process (arrow) inthe dorsal side of the head of Clarias batrachus)

Order - Perciformes (Family - Cichlidae)

The members of this family are distinguished by having a single nostril on each side of the head and the lateral line is in two sections, the anterior one curved, parallel to dorsal profile, the posterior one straight along the posterior part of the body.

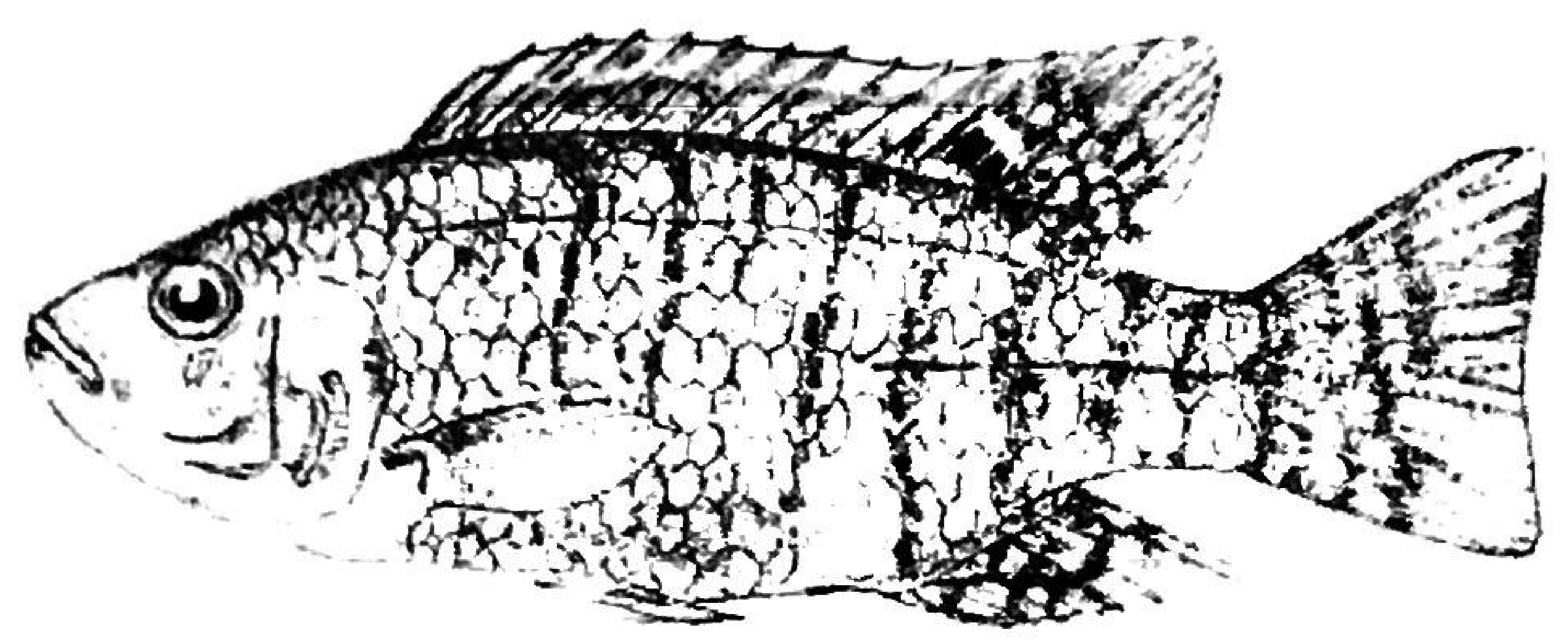

Figure 15. Oreochromis niloticus (Linnaeus, 1758)

Fishbase - Nile Tilapia, local - Tilapia. TL $=89 \mathrm{~mm}$. Locality; Lake Danao and Tubod River, important food fish. Introduced. Feed on phytoplankton, macrophytes, zooplankton and pollen grains. Mainly herbivorous. Mostly black, several bars on body (indistinct when adult; narrow vertical stripes on caudal; mouth points upwards; throat, pectorals, pelvic, caudal and dorsal tips become deep red while breeding. 


\section{Order - Perciformes (Sub Order - Gobioidei)}

A suborder of generally small fishes of similar shapes with large mouths; usually two dorsal fins, and a profile indicate of bottom dwelling habits. Three main families; Eleotridae, Gobiidae and Rhyacichthyidae.

Key to families

(1) Eleotridae

(1) Pelvic separate

(3) Pelvic close together; body compressed, rounded or only slightly depressed

(4) 7-12 segmented rays in 2 nd dorsal fin

\section{Eleotrididae}

(2) Gobiidae

(1) Pelvic united, at least posteriorly, at the base

(2) Two dorsal fins separate or connected at the base

(3) Rhyacichthyidae

(1) Pelvic separate

(3) Pelvics widely separated; body depressed, flat

Gobiidae

Rhyacichthyidae

Eleotridae is a small family similar to gobies, known as sleepers, distinguished from the gobies by their separate pelvic fins and six branchiostegal rays.

Key to species

(1) No teeth on vomer

(2) Angle of pre-operculum with a downward curved, strong spine (covered by skin, Figure 10) 


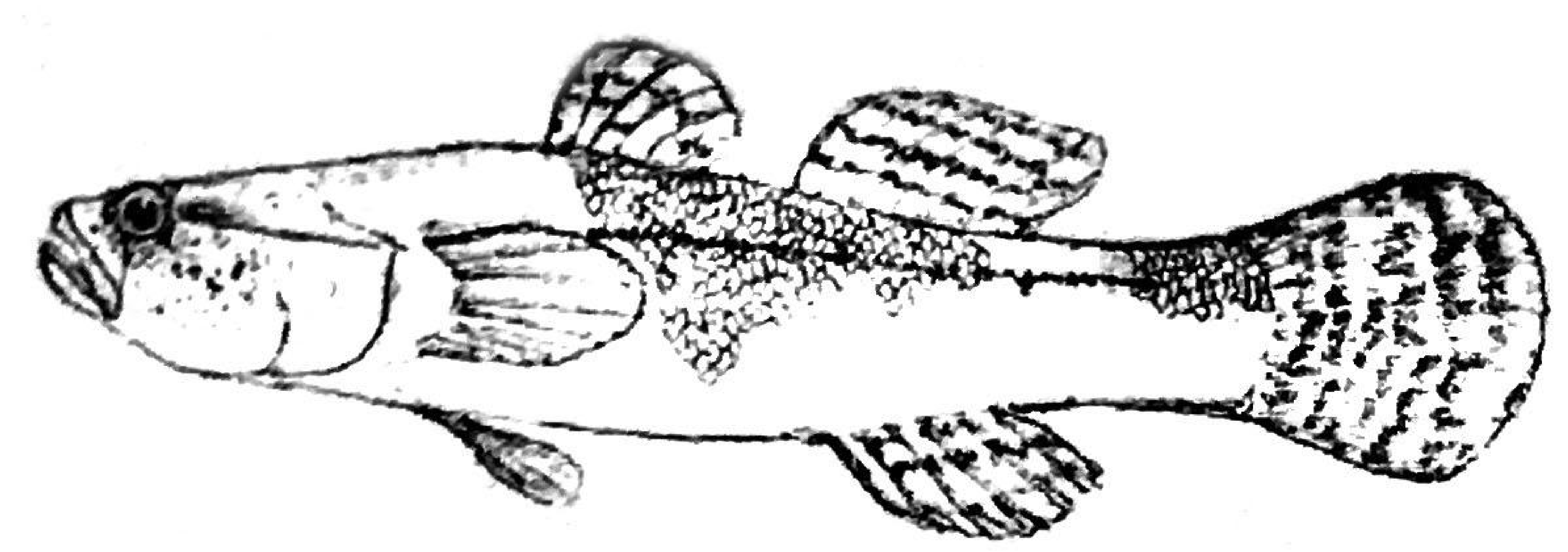

Figure 16. Eleotris melanosoma Bleeker, 1852

Fishbase - Broadhead sleeper, local - Sampoy (having a large head). $\mathrm{TL}=79 \mathrm{~mm}$. Locality - Tubod River. Carnivorous. Lateral row scales 46-58; usually 18-19 pectoral rays; 12-13 gill rackers on first gill arch; two longitudinal rows of papillae on opercle met posteriorly (Figure 17).

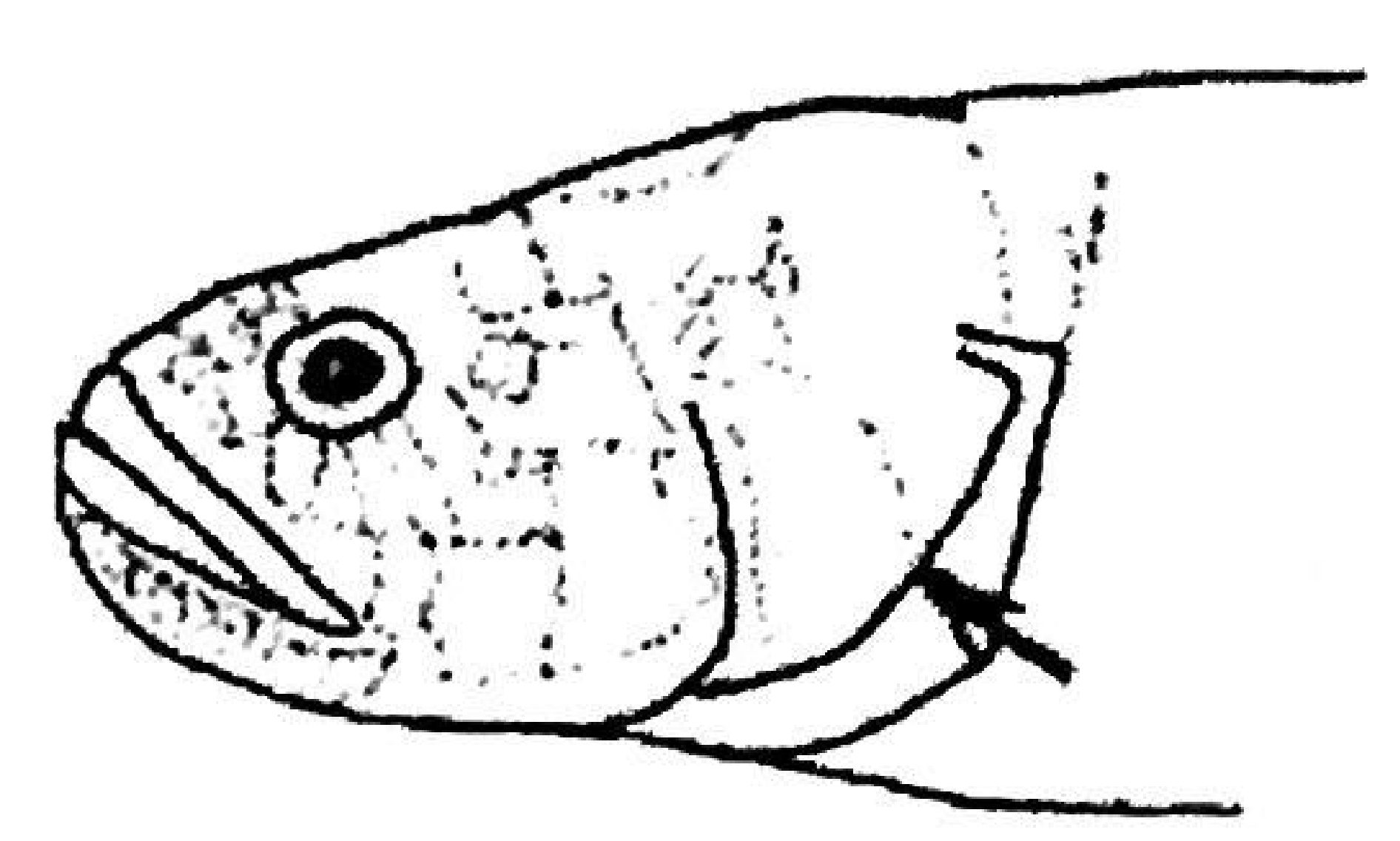

Figure 17. Row of papillae of the opercle of E. melanosoma; arrow point the longitudinal rowsof papillae meeting posteriorly.

Key to species

(1) No teeth on vomer

(2) Pre-opercle without spine 3

(3) No bony crest on head 5

(5) Body cylindrical at least anteriorly 6

(6) Head naked; first, or first and second branchiostegal rays end anteriorly in a spine (Figure 11); Belobranchus about 70 scales in lateral row; second dorsal with a spine and 7 rays 


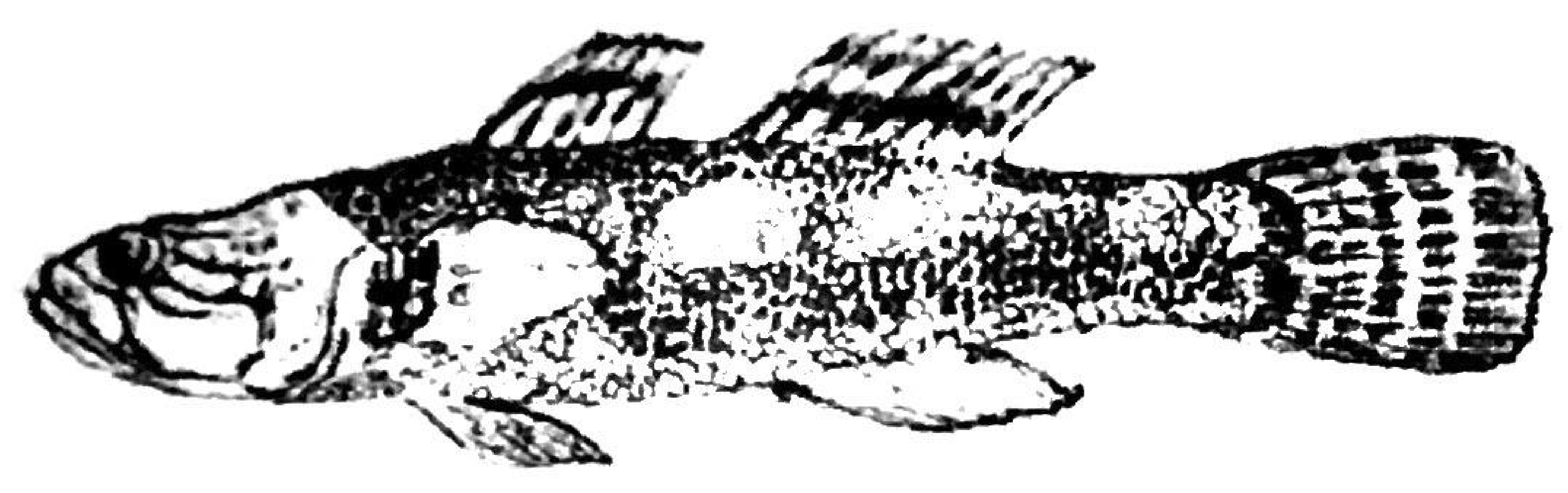

Figure 18. Belobranchus belobranchus (Valenciennes, 1837)

Fishbase - Throat-spine gudgeon, local - Sampoy (having a larger head). $\mathrm{TL}=117.8 \mathrm{~mm}$. Carnivorous. Head naked. Lateral row scales 70 ; first or first and second, branchiostegal end anteriorly in a spine (Figure 11).

Key to species

(1) No teeth on vomer

(2) Pre-opercle with out spine

(3) No bony crest on head

(5) Body cylindrical at least anteriorly

(6) Head partly or totally scaled

(7) Scales on body ctenoid at least on posterior part of the body

(8) 28-40 scales on lateral row

(9) About 28-30 scales on lateral row

Ophieleotris

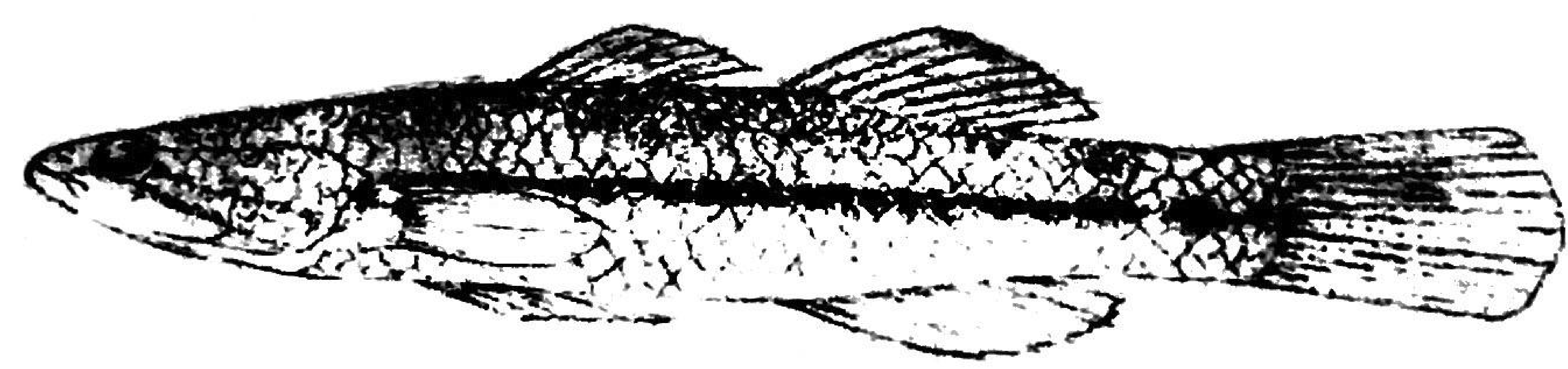

Figure 19. Ophieleotoris aporos (Bleeker, 1854)

Fishbase - Snakehead gudgeon, local - Sigamajon (moving very fast when disturbed). $T L=96.87 \mathrm{~mm}$. Locality; Tubod River. Feed on aquatic stages of Diptera, Lepidoptera, Trichoptera and diatoms. Mainly camivorous. Lateral row scales 30; pre-opercle scales 13-18; maxilliary extends to below anterior part of eye. 
Key to species

(1) No teeth on vomer 2

(2) Pre-opercle without spine 3

(3) No bony crest on head 5

(5) Body cylindrical at least anteriorly 6

(6) Body partly or totally scaled 7

(7) Body scales ctenoid, at last on posterior part of the body 8

(8) 60-102 scales on lateral line 10

(10) Teeth in upper jaw not or hardly enlarged;

60-70 scales in lateral raw Bunaka

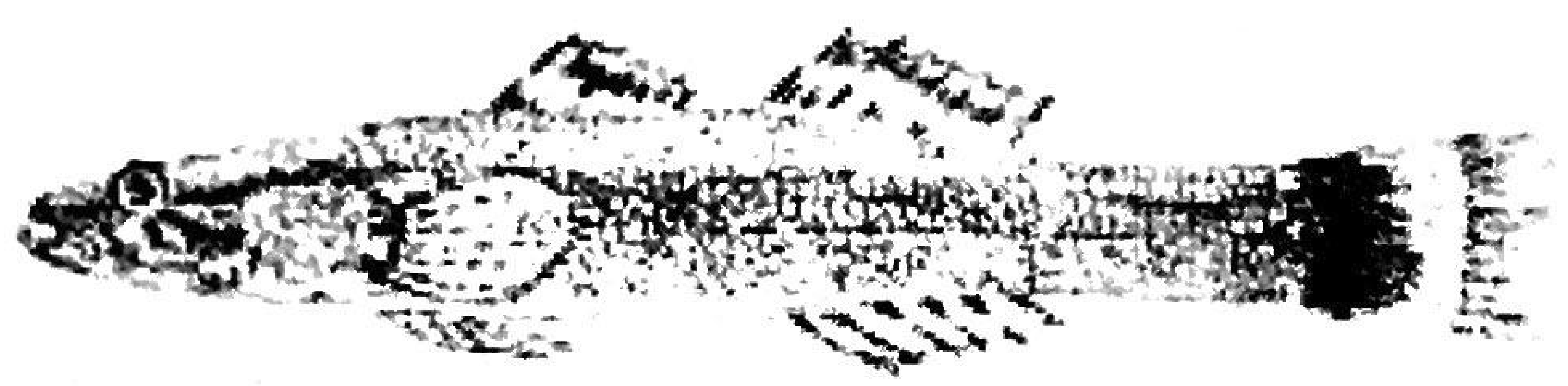

Figure 20. Bunaka gyrinoides (Bleeker, 1853)

Fishbase - Greenback gauvina, local - Anga. $T L=45.2 \mathrm{~mm}$. Locality; Tubod River. Lateral row scales 60-70; each scale with a dark spt; often forming longitudinal stripes on body.

Order - Perciformes (Suborder Gobioidei)

Family - Gobiidae

Family Gobiidae are distinguished by their united pelvic fins, which form a sucking disk (Figure 5) enabling them to retain their position in fast currents. Small stout fishes with tapering tails, broad fins, and 2 dorsal fins.

Key to genera

(1) Teeth of lower jaw in a single row

(36) Eye not elevated or rectile, without eye lid 
(40) Second dorsal with 7-12 segmented rays;

habitat: torrents

(41) Pelvic disc not adherent to the belly

(Figure 6b); 32-55 scales in lateral row

(42) Teeth on upper jaw not tricuspid

Sicyopus

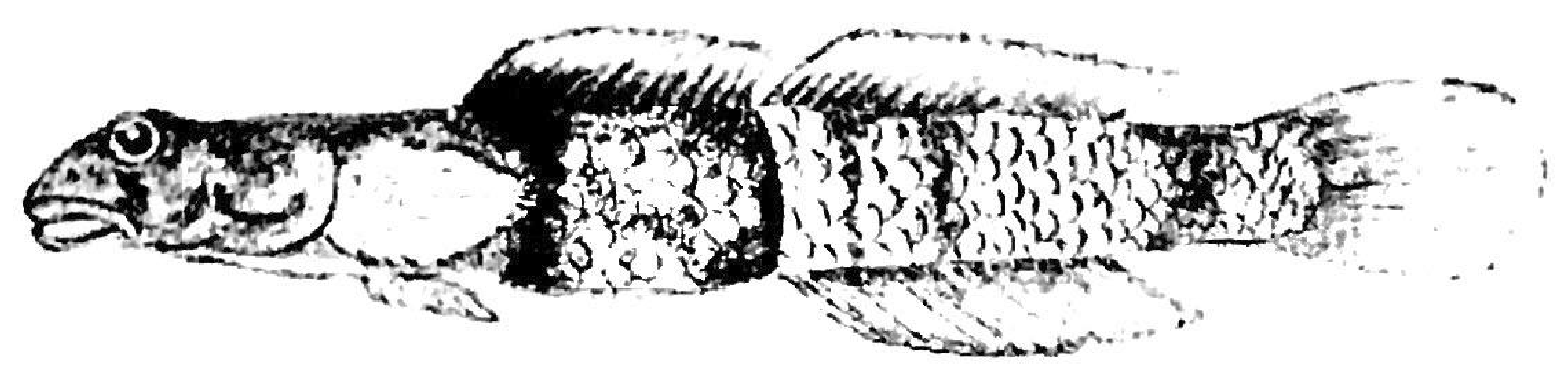

Figure 21. Sicyopus zosterophorum (Bleeker, 1857)

Local - Ton ton bato (jumping from place to place on rocks, under water). $\mathrm{TL}=4.4 \mathrm{~mm}$. Locality; Tubod River. Feed on aquatic stages of Ephemeroptera and other larval stages. Carnivorous. Lateral row scales $32-$ 33; head dark; male: body orange red with a broad dark bar below first dorsal fin; 2 narrow dark bars below second dorsal and one bar on caudle peduncle; Female: pale brown. Mainly inhabits in pools and sitting on the rocks.

Key to genera

(1) Teeth of lower jaw in a single row

(36) Eye not elevated; or erectile, with out eye lid

(41) Second dorsal with 7-12 segmented rays

(41) Pelvic disc adherent to the belly (Figure 6a);

$50-80$ scales in lateral line.

Sicyopterus

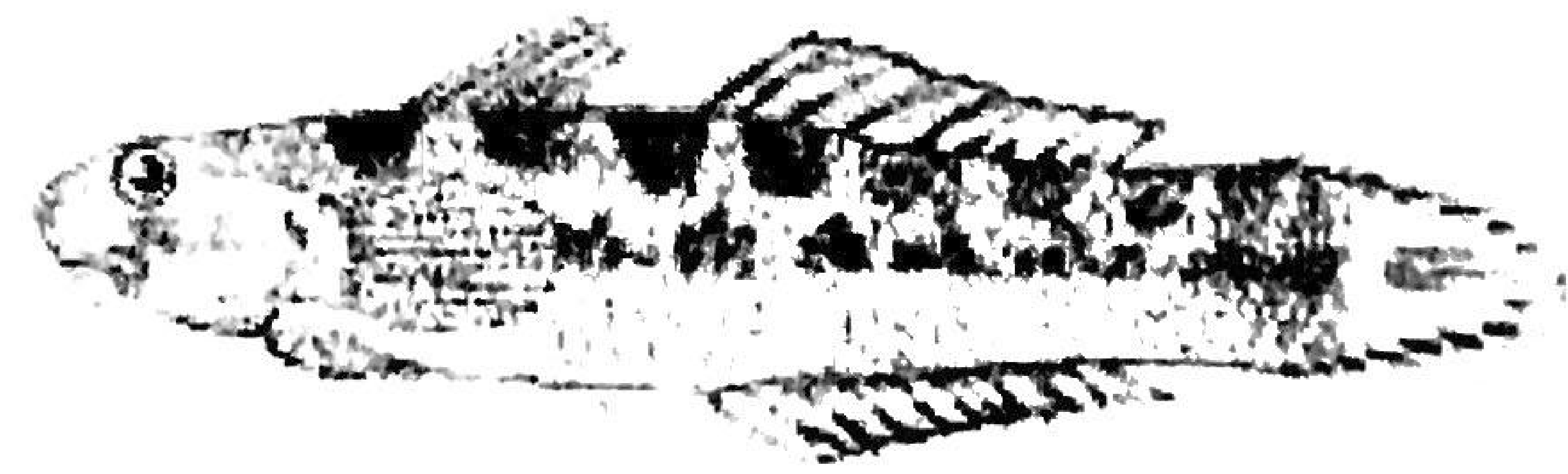

Figure 22. Sicyopterus micrurus (Bleeker, 1853) 
Fishbase - Clinging goby, local-Bodod. $\mathrm{TL}=36 \mathrm{~mm}$. Locality; Tubod River. Feed on diatoms and filamentous algae. Scraping on hard surfaces for biofilm, epilithic algae and diatoms. Preferred habitat is pools. Upper lip with one median and two lateral clefts (Figure 7). Lateral row scales 50-60; predorsal scales 24; light brown with about 8 bars across back; caudal with upper and lower sub-marginal stripes and a median longitudinal stripe, most conspicuous in females.

\section{Key to genera}

(1) Teeth of lower jaw in a single row

(36) Eye not elevated; or erectile, with out eye lid

(41) Second dorsal with 7-12 segmented rays

(41) Pelvic disc adherent to the belly (Figure 6a);

$50-80$ scales in lateral row

(42) Teeth in upper jaw closely set more or less tricuspid

\section{Stiphodon}

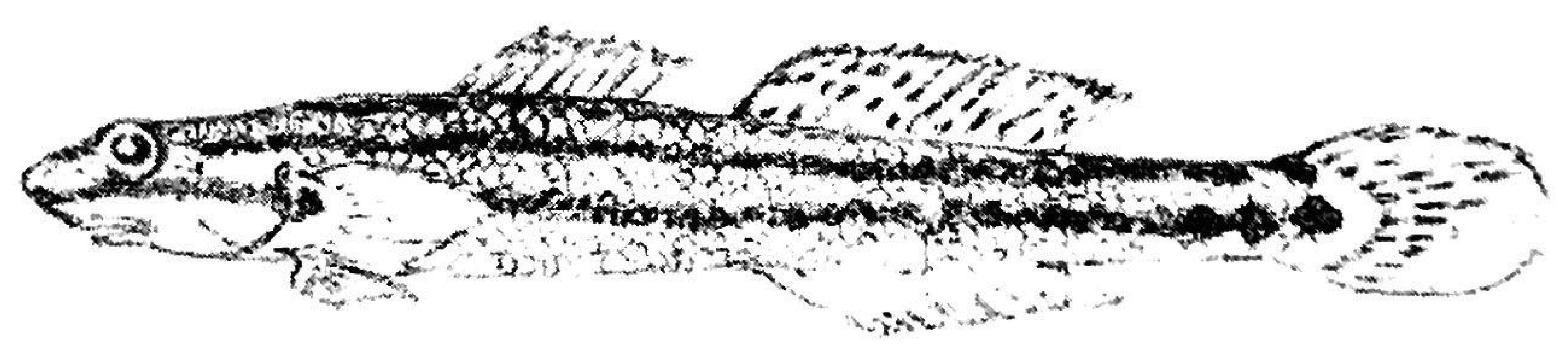

Figure 23. Stiphodon elegans (Steindachner, 1879)

$\mathrm{TL}=39 \mathrm{~mm}$. Locality; Tubod River. Bottom dwelling. Scraping on hard surfaces for biofilms, diatoms and filamentous algae. Preferred habitats pools and riffles. Females and juveniles yellowish brown with two black stripes; in males this pattern is obscured; 33-35 lateral row scales; $12-14$ pre-dorsal scales.

Key to genera

(1) Teeth on lower jaw in one or more rows

(2) Body scaled, at least in its posterior half

(3) No dermal ridge (Figure 24) in front of 1 st dorsal

(6) Cheek without raised ridges and flaps

(7) Shoulder girdle smooth or 
with minute bumps (Figure 25)

(10) Cheek naked (12)

(12) Upper pectoral rays usually not free; truncate to bilobed. mental frenum variable to absent (13) Pelvic thin, without fleshly lobe at tip of spines

(14) Head pores present

(21) Caudle longer or short than head; head pores type " $A$ " (without pore immediately behind anterior nostril, and a single anterior inter-orbital pore) (Figure 26)

(28) Gill opening extending only to level of lowermost pectoral ray or slightly below (Figure 9) (30) D VI: I, 8

Favonigobius

Figure 24. Dermal ridge on top of head
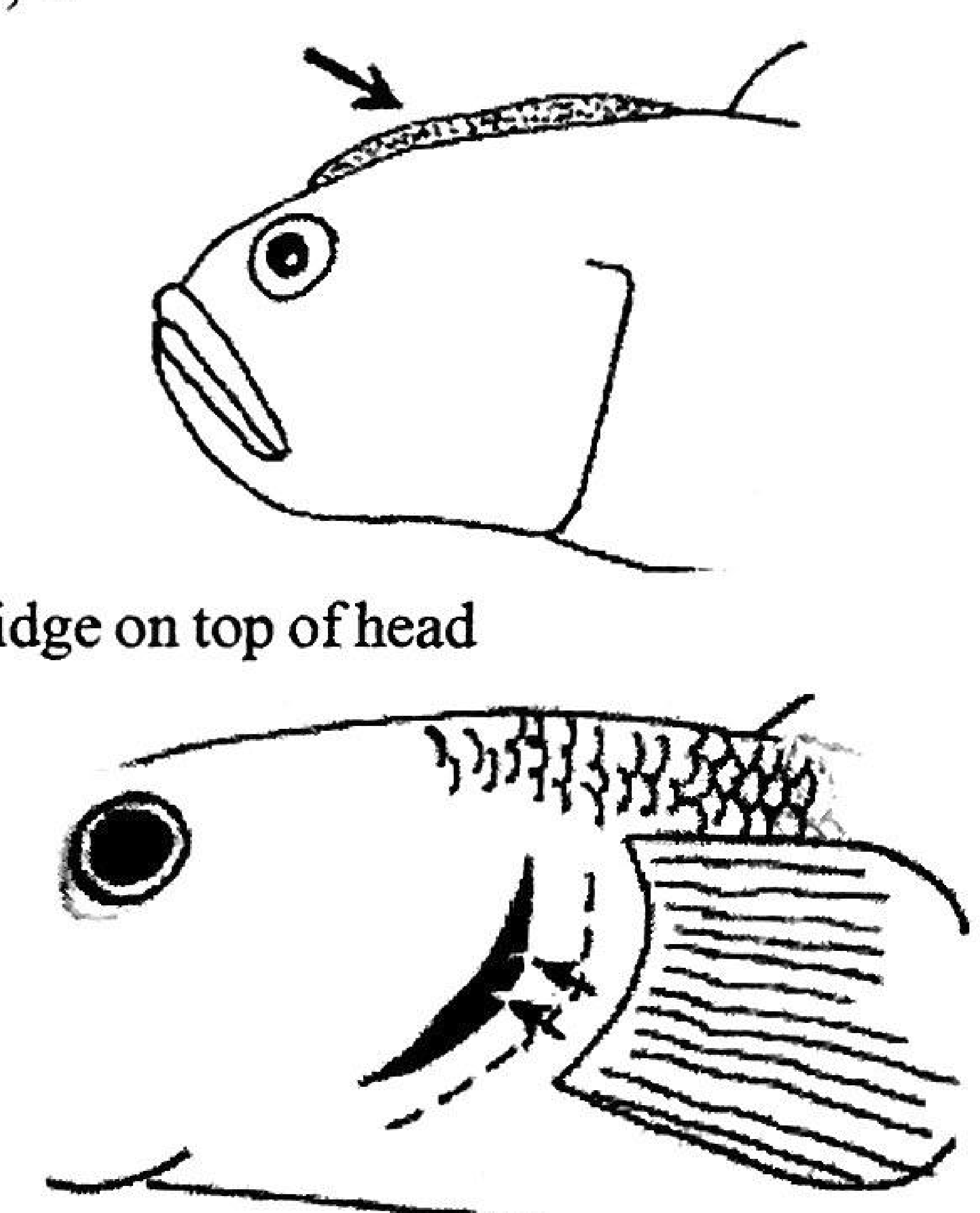

Figure 25. Finger like flaps (arrow) on shoulder girdle. Broken line indicates extent of posterior margin of opercle in Papillogobius sp

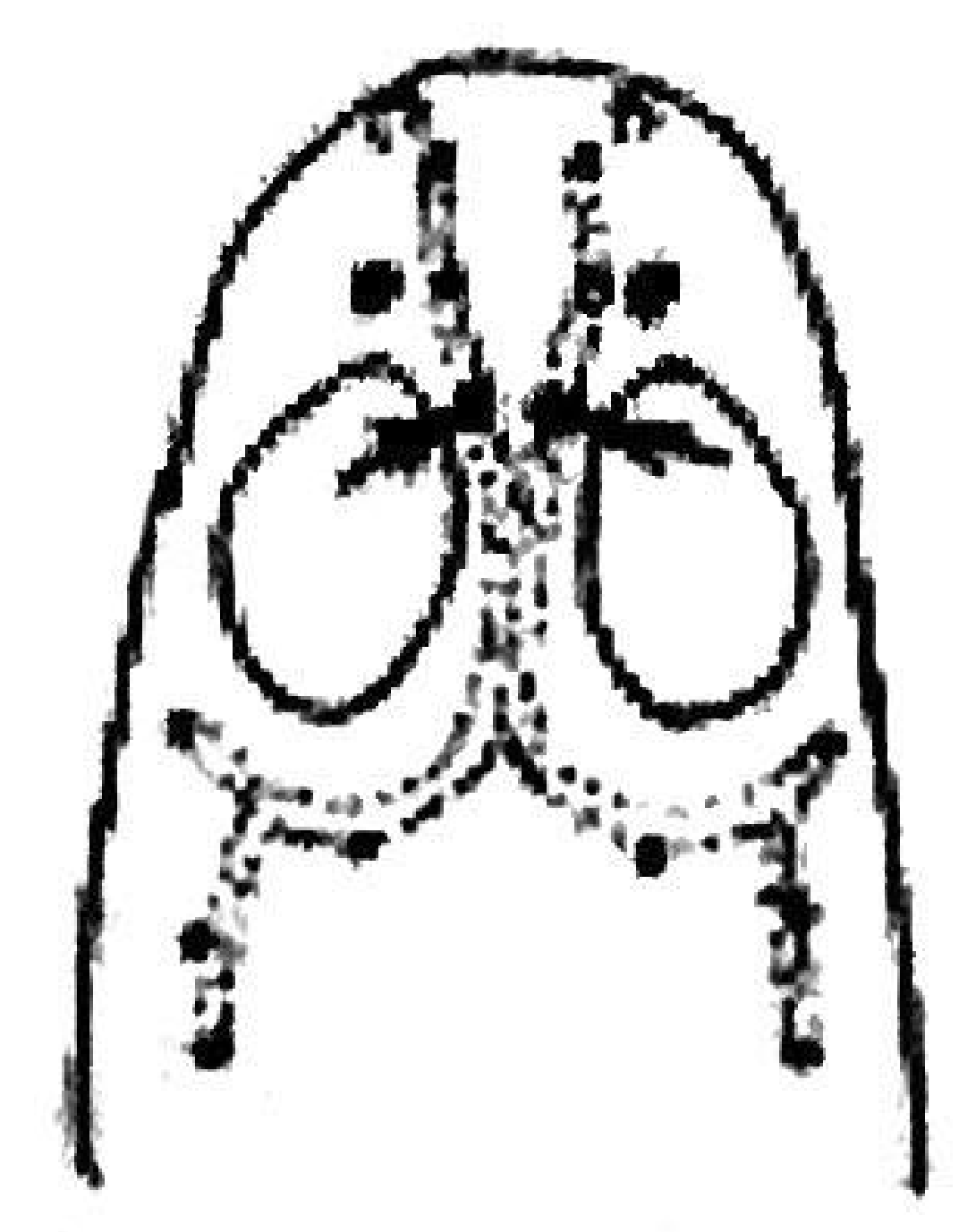

Figure 26. Head pores of type "A". Black dots = posterior nostrils; arrow shows the anterior inter-orbital pores 


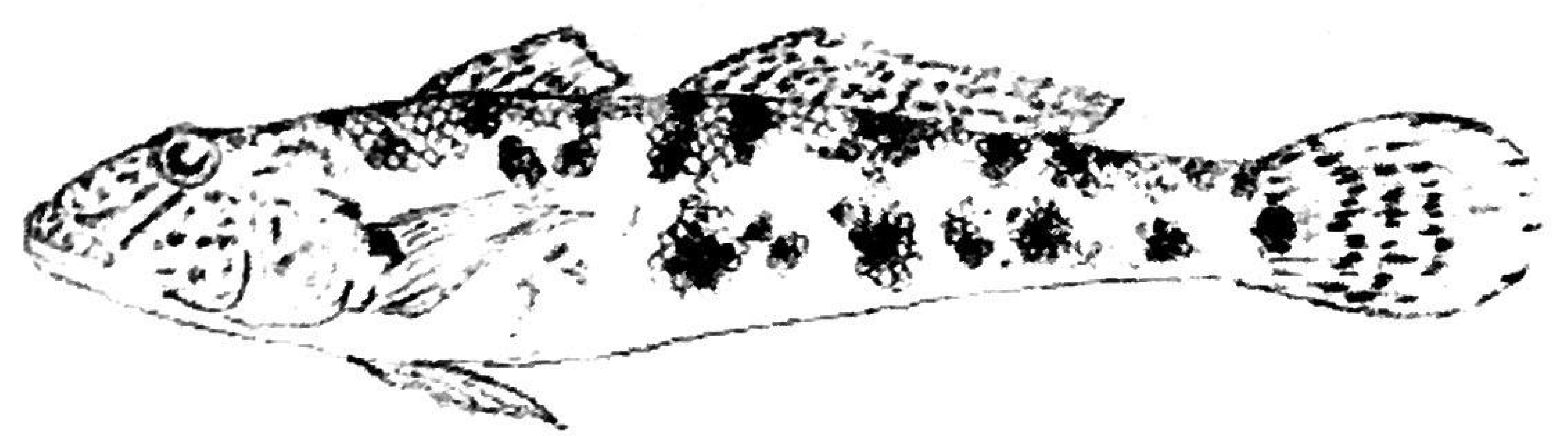

Figure 27. Favonigobius reichei (Bleeker, 1853)

Fishbase - Indo-pacific tropical sand goby. $\mathrm{TL}=87 \mathrm{~mm}$. Feed on aquatic stages of Ephemeroptera and other insects, Cladophora, and filamentous algae. Mainly 15 carnivorous. Preferred habitat sandy bottoms of pools. Rows a, c and cp of cephalic papillae pattern multiple and disorganized (Figure 28); 0-3 pre-dorsal scales; black bar through eye at $40^{\circ}$ to longitudinal axis of body.

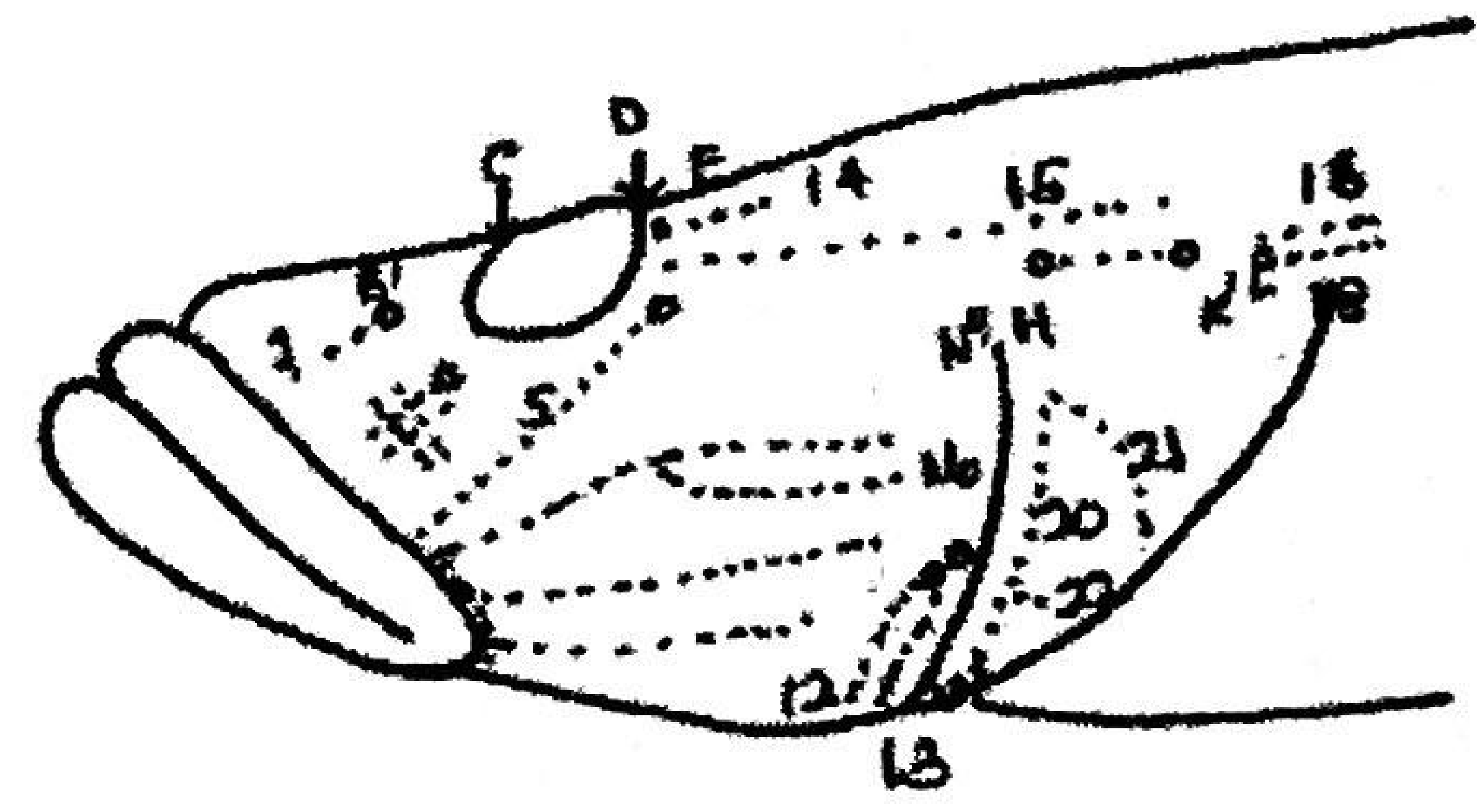

Figure 28. Cephalic papillae pattern in Glossogobius giuris

Key to genera

(1) Teeth of lower jaw in two or more rows

(2) Body naked Schismatogobius

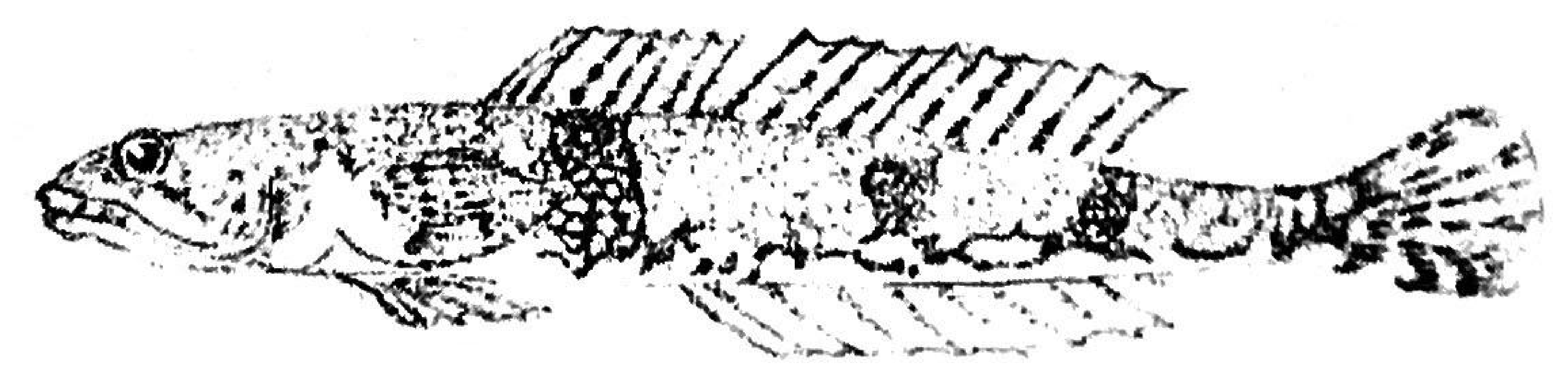

Figure 29. Schismatogobius marmoratus (Peters, 1869) 
Local - Sampoy (having a large head). $T L=41 \mathrm{~mm}$. Body naked, body depth 4.0-5.0 $\mathrm{mm}$ in standard length.

Key to genera

(1) Teeth on lower jaw in one or more rows

(2) Body scaled, at least in its posterior half

(3) No dermal ridge (Figure 24) in front of 1st dorsal

(6) Cheek without raised ridges and flaps

(7) Shoulder girdle smooth or with minute

(10) Cheek naked

(12) Upper pectoral rays usually not free; tongue truncate to bi-lobed; mental frenum variable to absent

(13) Pelvic thin, without fleshly lobe at tip of spines

(14) Head pores absent

(15) DVI; 0-I, 6-8; 22-55 scales in lateral row; up to $60 \mathrm{~mm} \mathrm{SL}$

(16) Body translucent or brown with spotted, barred, stripped patterns; mouth larger in males than in females

(17) D VI; 6-8; anal and second dorsal without spines; 17-segmented rays in caudle; head rounded

(18) Body fully scaled; body with dark bands or spots

(19) 22-27 scales in lateral row

(20) Body with spots of diffuse bands; size less than $15 \mathrm{~mm}$ SL

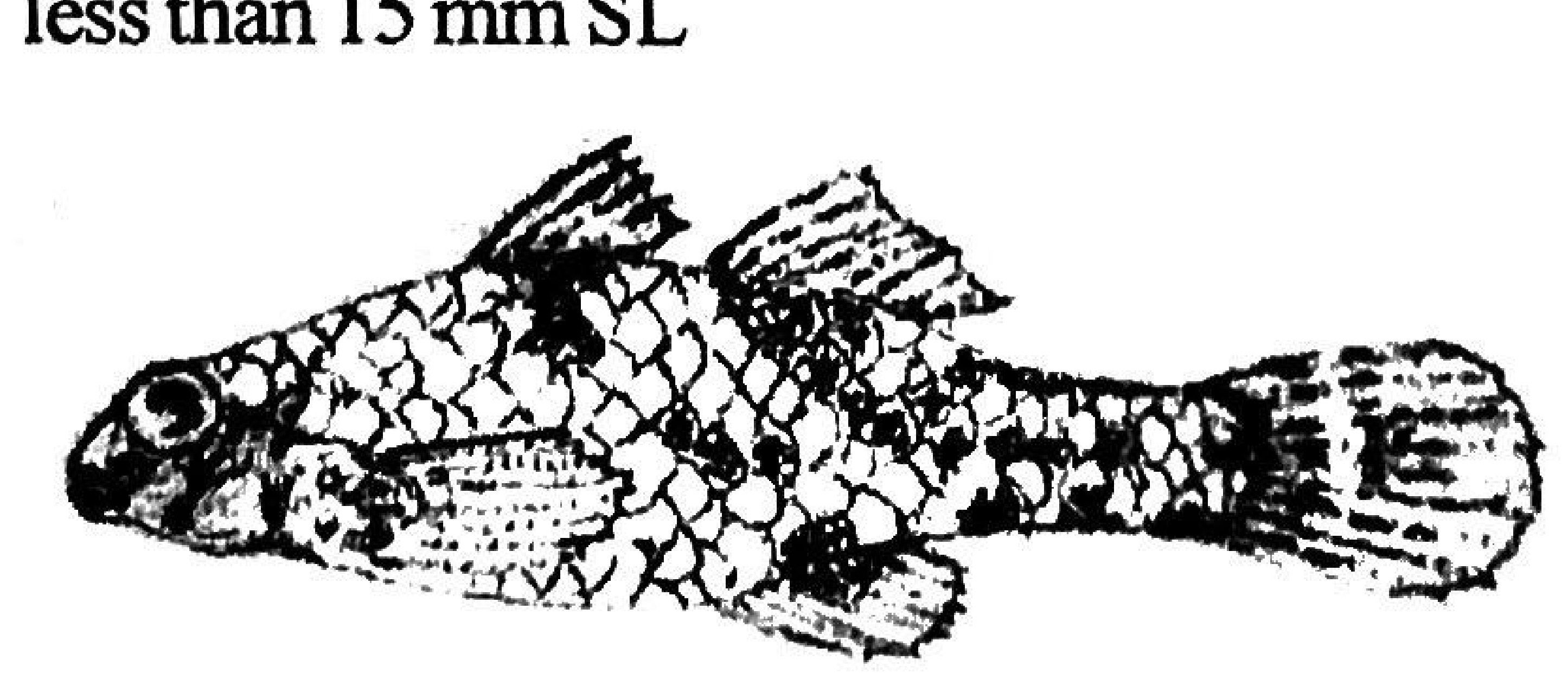

Padanka

Figure 30. Padanka pygmaea Herre, 1927 
Fishbase - Dwarf pigmy goby. $\mathrm{TL}=35.5 \mathrm{~mm}$. Locality - Tubod River. Three black spots along the lower margin of caudle peduncle (Figure 9). 2224 lateral row scales. $14-15$ pectoral rays.

Key to genera

(1) Teeth on lower jaw in one or more rows

(2) Body scaled, at least in its posterior half

(3) No dermal ridge (Figure 24) in front of 1 st dorsal

(6) Cheek without raised ridges and flaps

(7) Shoulder girdle smooth or with minute

(10) Cheek naked

(12) Upper pectoral rays usually not free; tongue truncate to bi-lobed; mental frenum variable to absent

(13) Pelvic thin, without fleshly lobe at tip of spines

(14) Head pores present

(21) Caudle longer or short than head; head pores type "A" (without pore immediately behind anterior nostril, and a single anterior inter-orbital pore) (Figure 26)

(28) Gill opening extending to below rear margin of pre-opercle or further forward (Figure 9)

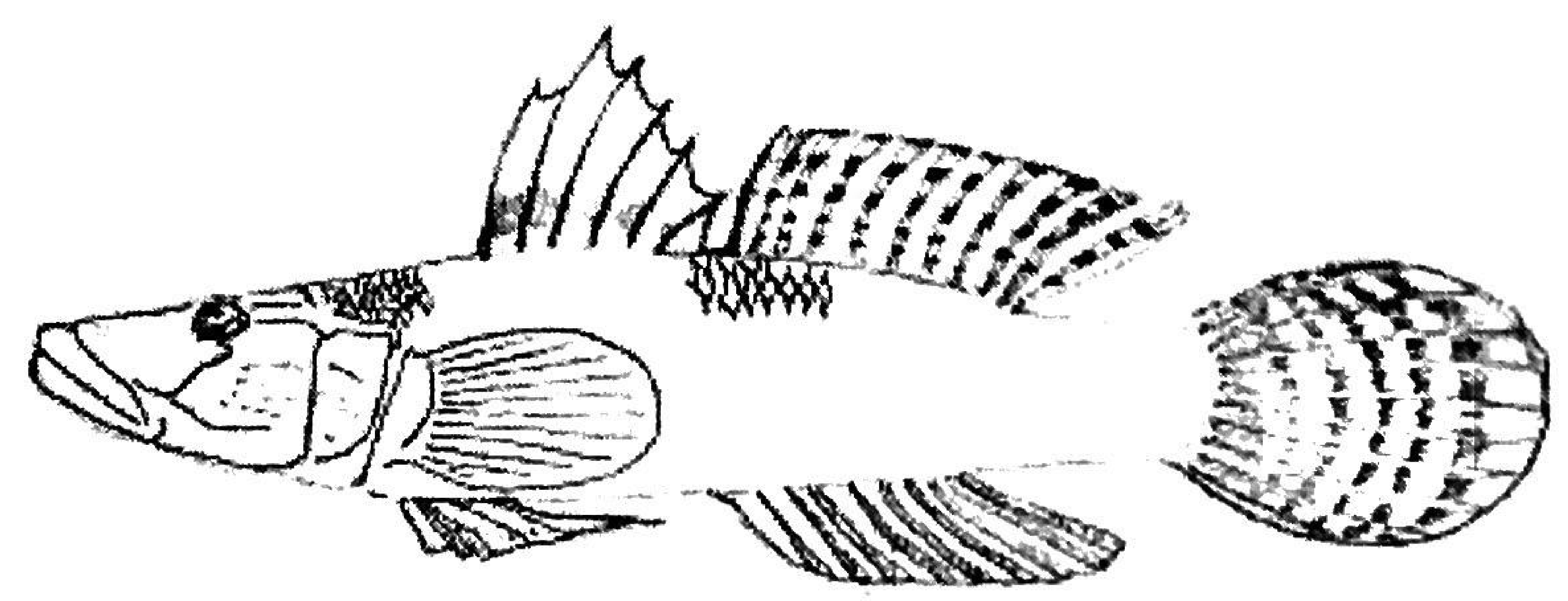

Figure 31. Glossogobius giuris (Hamilton, 1822) 
Fishbase - Tank goby, local - Bul-a and Mangnay. $T L=260 \mathrm{~mm}$. Locality; Lake Danao and Inawasan River. Feed on shrimps and small gobies. Carnivorous. Lateral rows, lines 15 and 16 separated, lines 17 and 18 separated, lines 20, 21 and 22 un-branched (Figure 28).

17

Order - Perciformes, Sub Order - Gobioidei (Family - Rhyacicthyidae)

Rhyacicthyidae are adapted to bottom living with completely flat ventral side.

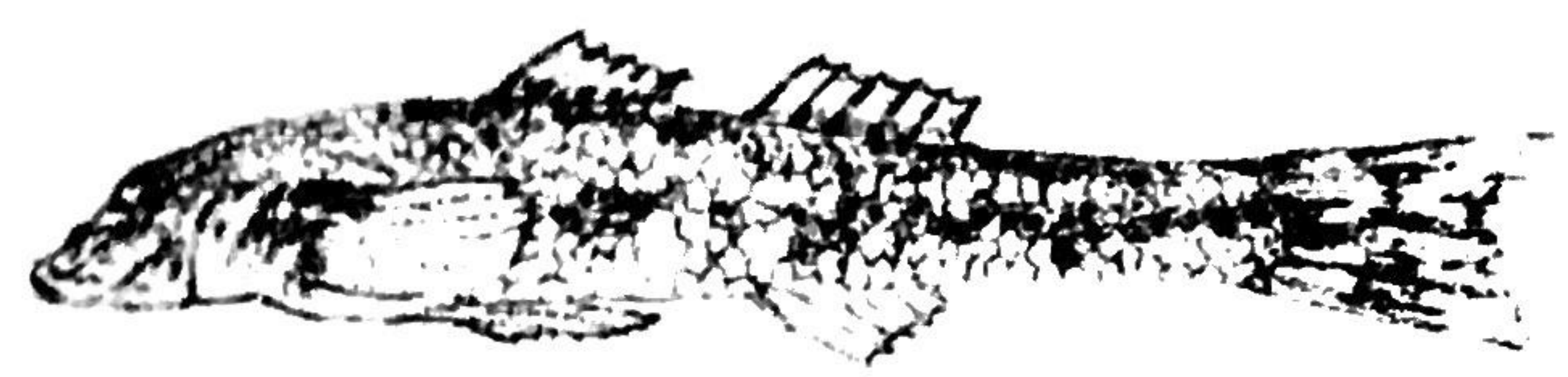

Figure 32. Rhyacicthys aspro (Valenciennes, 1837)

Fishbase - Loach goby; local - Dapigan (appears like a leaf when under water). $T L=73 \mathrm{~mm}$. Locality; Tubod River. Feed on aquatic stages of Ephemeroptera, Diptera, other adult insects and crustaceans. Prefer pools close to small waterfalls. D VIII; 1, 8-9; bottom dwelling and well camouflaged.

Order - Perciformes (Family - Kuhliidae)

Family Kuhliidae are commonly known as flag tails. The caudal fin has distinct black bars. The head and body are covered with ctenoid scales.

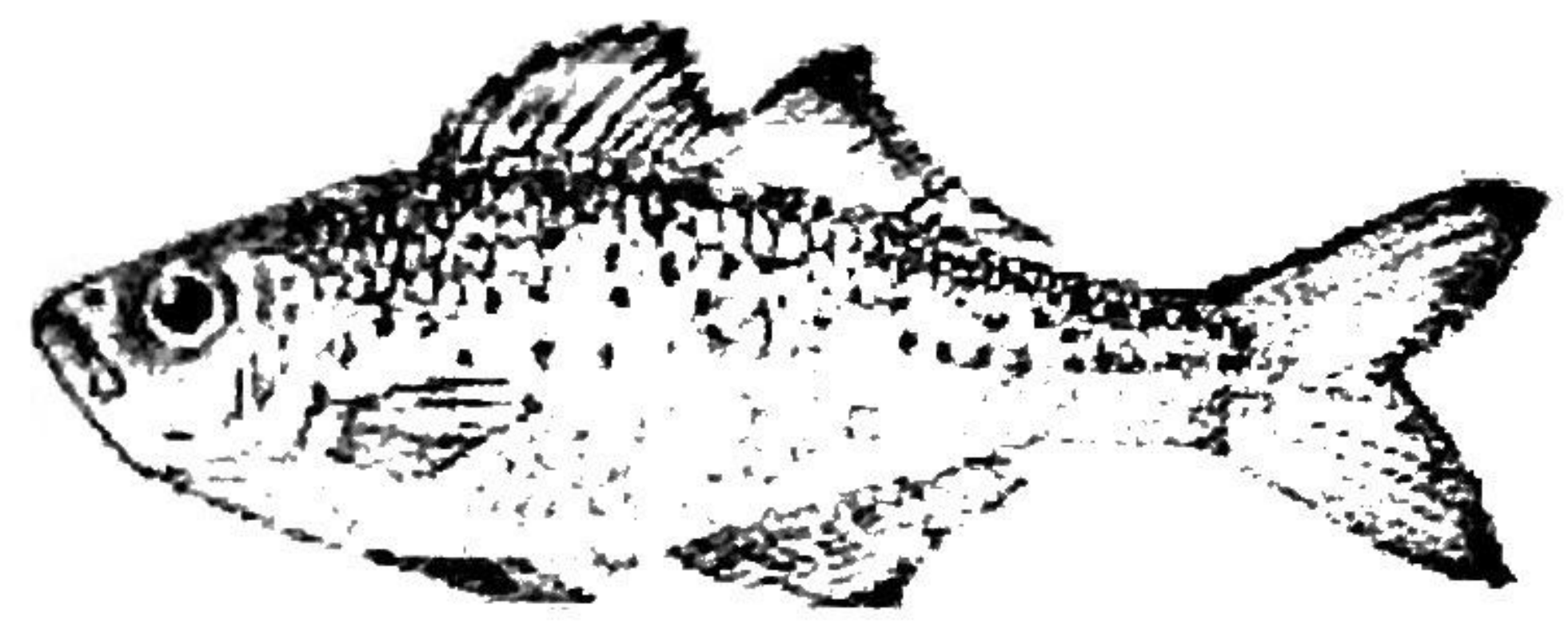

Figure 33. Kuhlia marginata (Cuvier, 1829) 
Fishbase - Dark margined flag tail; Local-Domagon; means swimming very fast. Locality; Tubod River. Feed on aquatic stages of Ephemeroptera, Diptera, Odonata, and adults of insects and Odonata. Preferred habitats are pools of about $1 \mathrm{~m}$ in depth. TL $=113 \mathrm{~mm}$. Lateral line scales 40-45; Maxillary not reaching to below middle of the eye; snout shorter that eye; length of base of soft anal longer than that of soft dorsal; 16-19 gill rackers on lower part of fish gill arch.

\section{Order - Anabantoidei (Family - Osphronemidae)}

Anabantoidei includes 5 families characterized by the possession of a labyrinth in the gill chamber.

Key to family

(1) Compressed, oblong body, snout short, mouth opening oblique and small, anal fin long, not notched (2)

(2) Jaws with teeth; caudal rounded; lanceolate or emarginated; if caudle emarginated then pelvic transformed into a long filament (3)

(3) Lateral line complete and continuous Osphronemidae

The short first spine and the long filamentous second spine in the pelvic fin characterize family Osphronemidae.

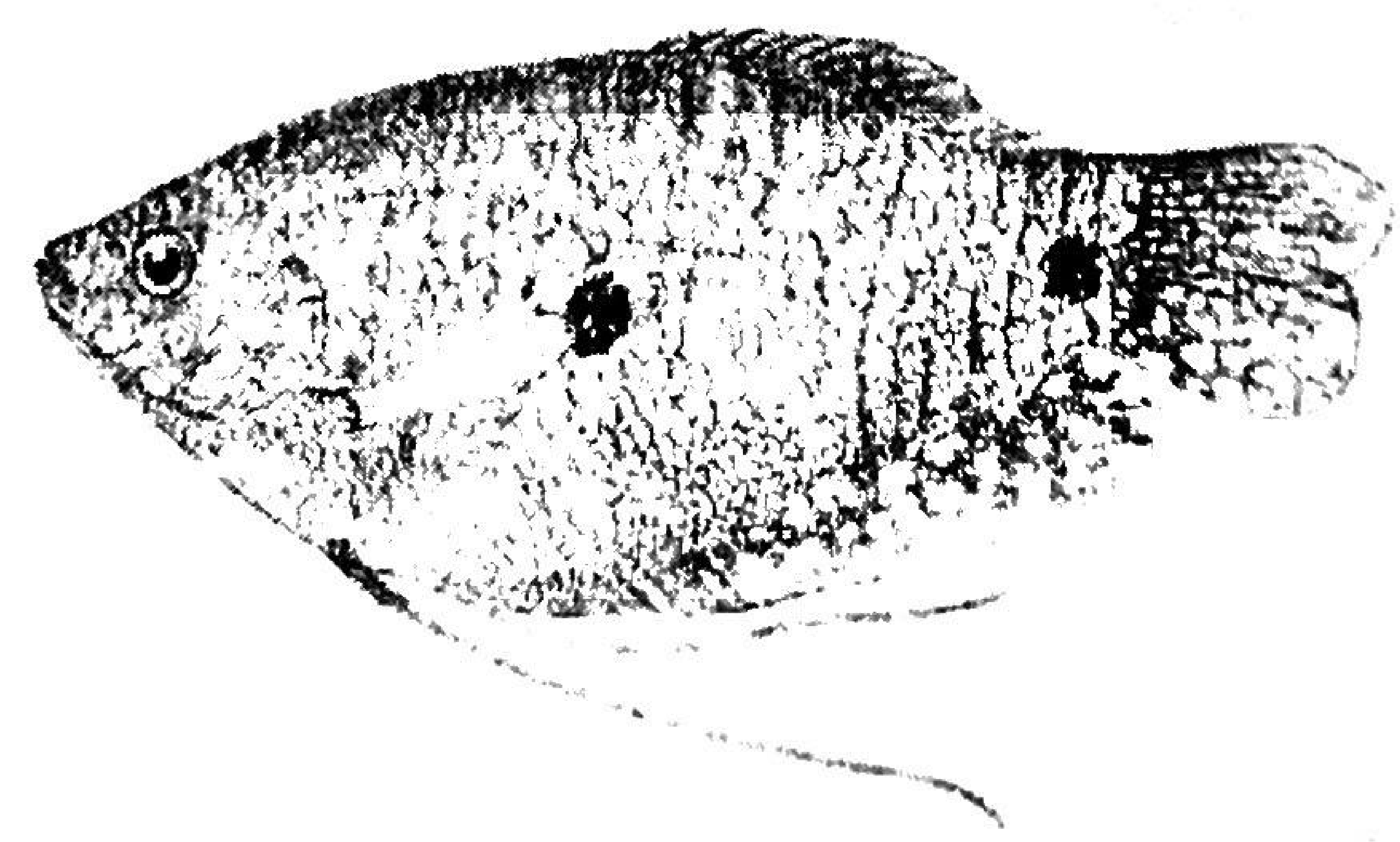

Figure 34. Trichogaster trichopterus (Pallas, 1770)

Fishbase - Three spot Gourami; local - Gourami. Locality; lake Danao. $\mathrm{TL}=109 \mathrm{~mm}$. 
Introduced species.

Order - Cyprinidontiformes (Family-Poeciliidae)

Poeciliidae are livebearers. Male has a modified anal fin (Gonopodium) through which sperm is introduced into the female genital pore.
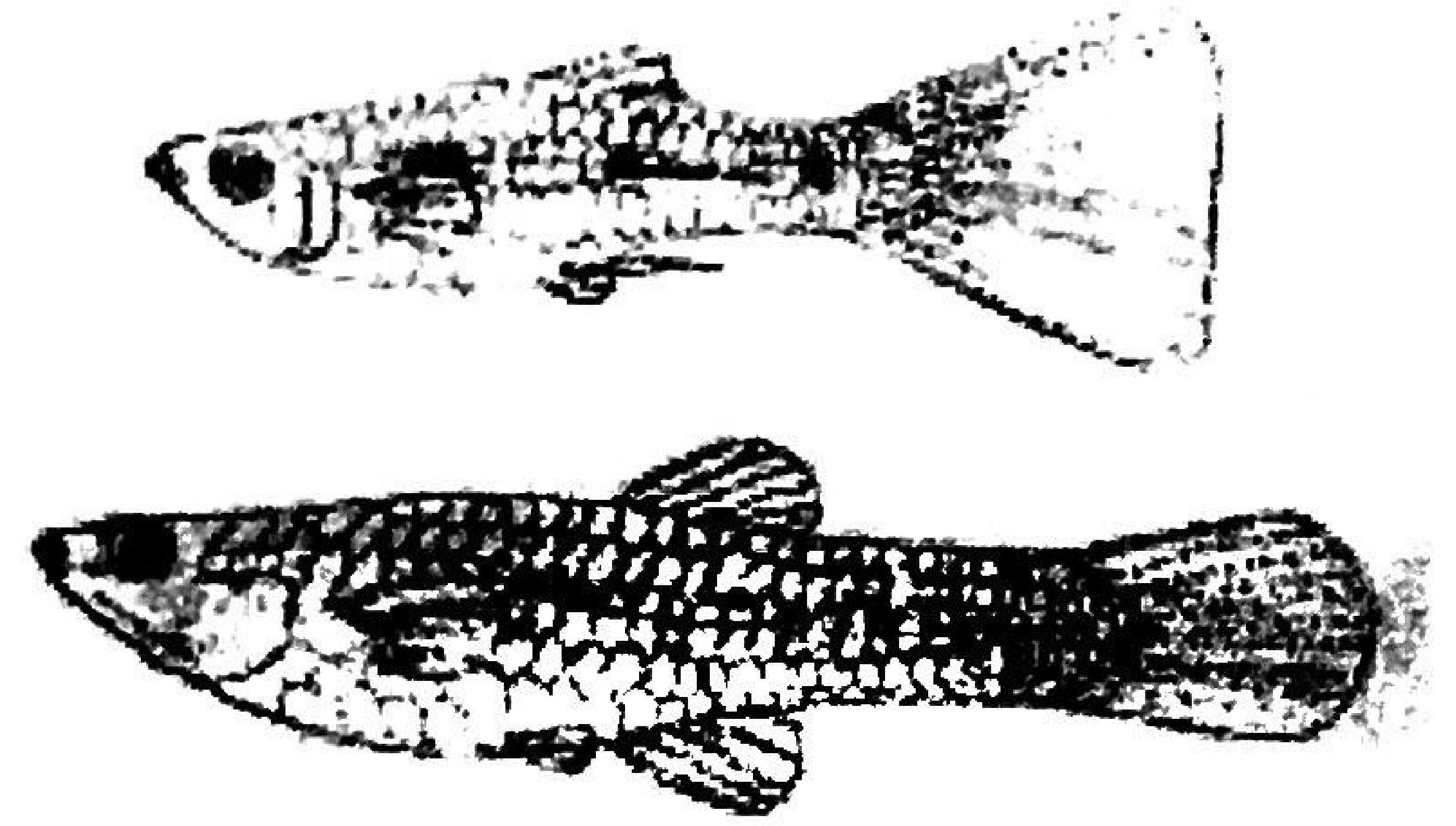

Figure 35. Poecilia reticulata Peters, 1859 (above - male, below-female)

Fishbase-Guppy; local-Buntis buntis(Tubod River); meaning "pregnant women"; Burod (Lake Danao). Locality; Lake Danao and Tubod River. Introduced. $\mathrm{TL}=48 \mathrm{~mm}$. Not adapted for fast current, living mostly in slow moving areas of the Tubod River and in the inshore area of Lake Danao. Feed on insects, diatoms and filamentous algae. Male brightly colored with black spots above anal and below dorsal fins; various color forms.

Order - Syngnathiformes (Family - Syngnathidae)

Syngnathidae have segments formed by bony plates below the skin (Figure 35). All have tubular snouts with a small mouth.

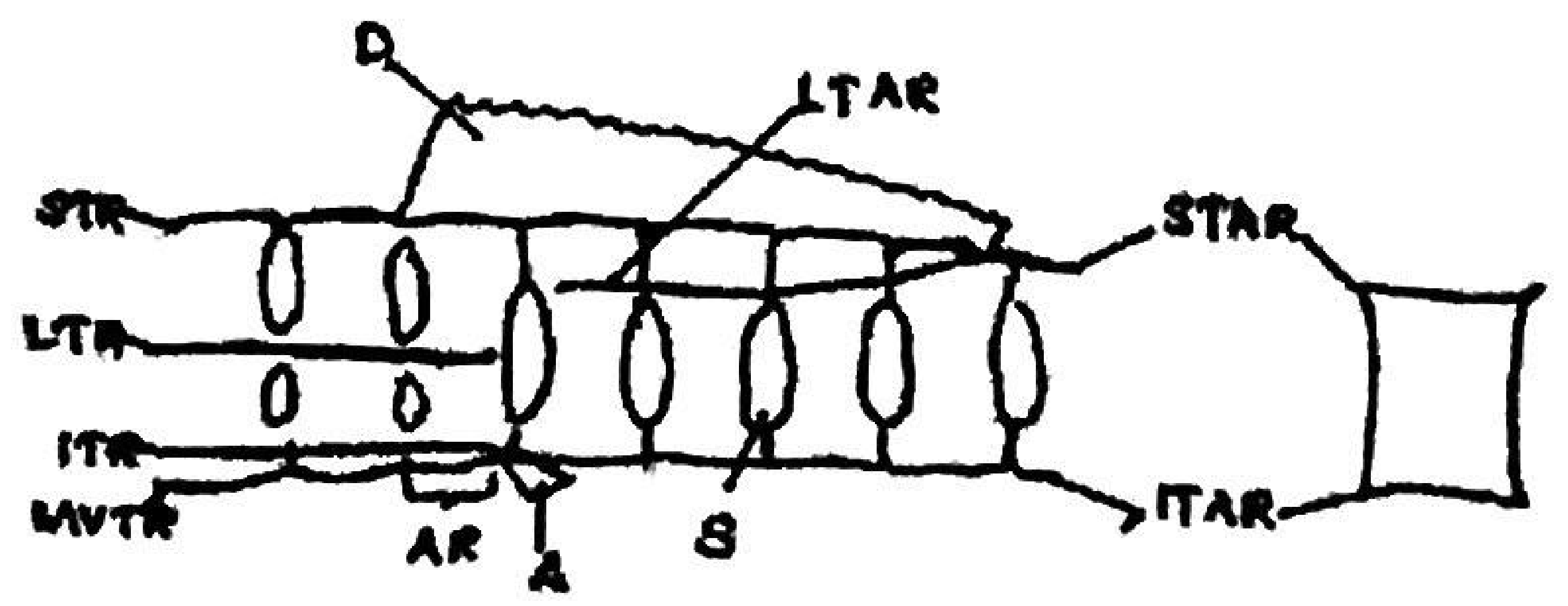

Figure 36. Ridges and rings of a pipefish at the level of dorsal and anal fins (A-anal fin, AR-anal ring, ITAR - first tail ring, ITR - inferior trunk ridge, LTAR - lateral tail ridge, LTR - lateral trunk ridge, MVTR - median ventral trunk ridge, S scutella, STAR - superior tail ridge, STR - superior tnunk ridge, D - dorsal fin). 


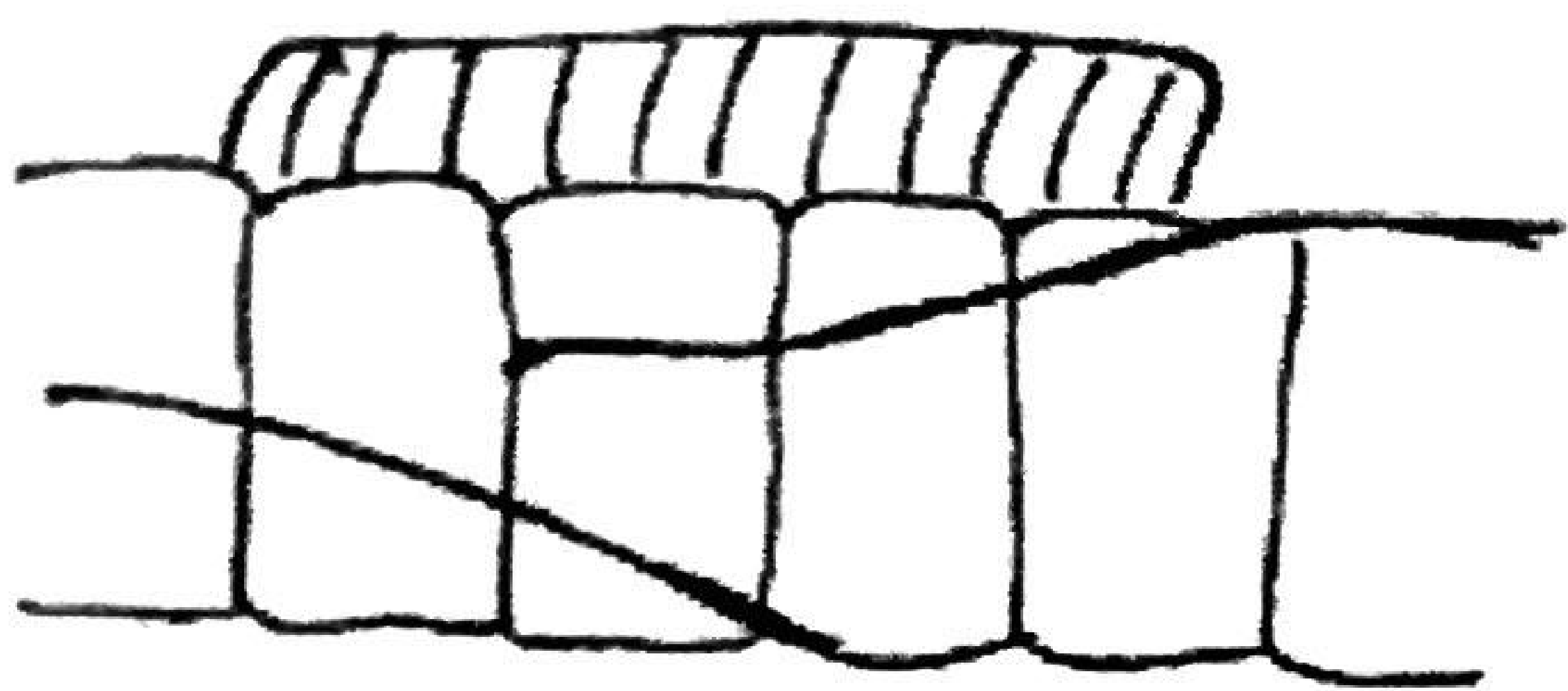

Figure 37. Connection between trunk and tail ridges in Microphis sp

Key to the genera

(1) Superior trunk and superior tail ridges discontinuous;

lateral trunk ridge confluent with inferior tail ridge

(2) Inferior trunk and inferior tail ridges discontinuous, lateral trunk ridge confluent with inferior tail ridge (Figure 38).

Male brood area under the trunk

Microphis

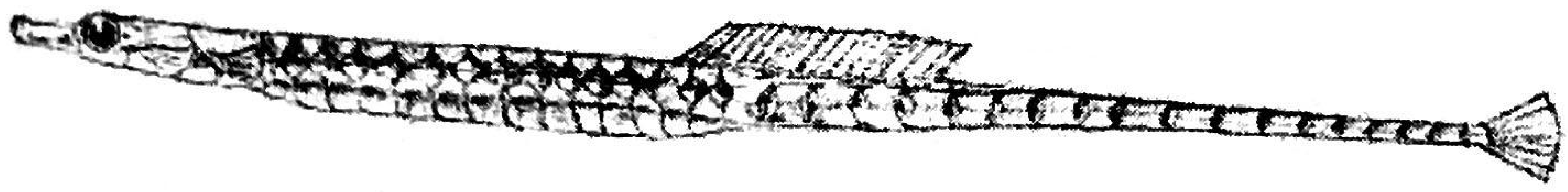

Figure 38. Microphis ocellatus (Duncker, 1910)

Fishbase - Flatnose pipe fish; local - thokog thokog; means like eakel?. Locality; Tubod River. Feed on aquatic stages of Ephemeroptera and Chironomidae, other insects, diatoms and filamentous algae. Preferred marginal zone of streams within submerged aquatic plants and among the fine roots. TL $=120 \mathrm{~mm}$. Opercle with longitudinal ridge, distinct and complete and with one or more supplemental ridges (Figure 3); snout depth 3.6-4.8 times in its length; scutella without keel (Figure 4a), sometimes keeled on dorsal side 1 st and 2 nd ridges (Figure $4 \mathrm{~b}$ ); ocelli on lateral trunk ridge.

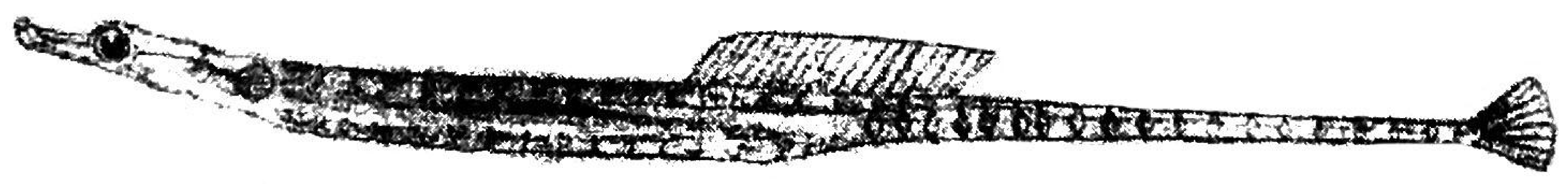


Fishbase - Pipe fish; local - thokog thokog (like eakel). TL $=117 \mathrm{~mm}$. Feed on aquatic stages of Ephemeroptera and Chronomidae, other insects, diatoms and filamentous algae. Preferred marginal zone of streams within submerged aquatic plants and among the fine roots. Longitudinal ridge on operculum is vestigial or absent (Figure $3 b$ ). Lateral and inferior trunk ridges distinct; large specimens are with dark spots on pectoral base and ocellate spots on side of trunks.

Order - Scorpaeniformes (Family - Scorpaenidae)

Family Scorpaenidae have strong dorsal spines, many long spines on the head, and bony plates from the eye across the cheek to the gill cover. Some species are important food fishes.

Key to genera

(1) Anterior dorsal spines not separated from rest of the fin.

Body naked, no scales

Tetraroge

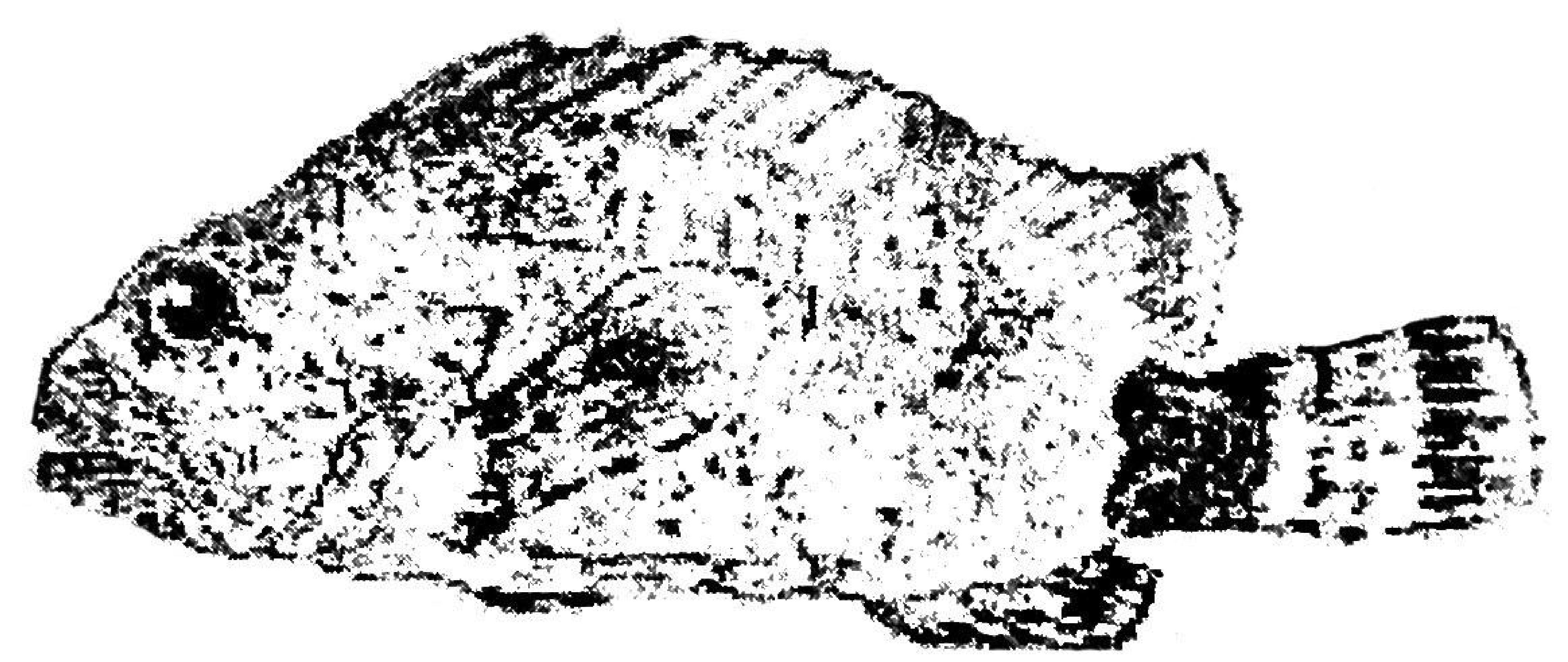

Figure 40. Tetraroge niger (Cuvier, 1829)

Fishbase - Scorpion fish; local - Nopo; meaning "like a scorpion". Locality; Tubod River. Preferred habitats are hideouts in between rocks in pools. $\mathrm{TL}=70 \mathrm{~mm}$. No barbles at front of chin; no deep groove on both sides of dorsal origin above and behind eye. 


\section{ACKNOWLEDGEMENT}

Many thanks for all the help, information and experiences about fishing, which were given by Emik Gumba, Noel Tabaranza, Berny Tabaranga and Jun Jun Pulia in Cienda Village, and by the ranger of the Danao National Park: Mr. Boy. Many thanks also to Yamal T Perera from the University of Kelaniya, Sri Lanka, for extremely nice drawings of fishes.

\section{REFERENCES}

FROESE, R. and D. PAULY, Editors. 2000. FishBase 2000: concepts, design and data sources. ICLARM, Los Baños, Laguna, Philippines. 344 p.

GÖLTENBOTH, F., M. LEICHTFRIED, W. S. WELINAGE, J. G. BAJARIAS, A. FOTHE, C. HUTTER, M. MROTZEK, J. POGOSA and S. WELLER. 2005. Preliminary results of freshwater investigations of Lake Danao and Inawasan River in the midmountain area of Leyte, Philippines. Proc. 10. Intern. Seminar and Workshop on Tropical Ecology, Leyte State Univ., Baybay, Philippines: 52-59.

KOTTELAT M., A. J. WHITTEN, S. N. KARTIKASARI, S. WIRJOATMODIO.1993. Freshwater Fishes of Western Indonesia and Sulawesi. Periplius Editious Ltd., $293 \mathrm{pp}$.

LEICHTFRIED, M, F. GÖLTENBOTH, CH.APPEL, W. S.WELIANGE, S. LANG, MAZO, R. OMEGA, and J. POGOSA. 2002. Investigations of lotic freshwater habitats on the Tubod river, Leyte, Philippines. Proc. 9th Intern. Seminar and Workshop on Trop. Ecol., Leyte State University, Baybay, Philippines: pp. 1-16.

WELIANGE W. S. 2002. Some aspects of feeding ecology of fish assemblage in Tubod River, Leyte, Philippines. Proceedings of the 9th International Seminar and Workshop on Tropical Ecology. Aug. 26 - Sept. 7, 2002. Leyte State University, Baybay, Leyte, Philippines.

WELIANGE, W. S. 2002. Traditional fishing practice and resource management in Tubod River, Leyte, Philippines. Proc. 9th Intern. Seminar and Workhsop on Trop. Ecol., Leyte State University, Baybay, Philippines: pp. 17-21.

WELIANGE, W. S. and J. POGOSA, 2005. Fish Fauna, Fisheries and some aspects of the ecology of the fishes in Lake Danao, Ormoc, Philippines. Proc. 10. Intern. Seminar and Workhsop on Trop. Ecology, Leyte State Univ., Baybay, Philippines: pp. 6063. 